\title{
ECONOMIC PAPERS
}

\section{European Commission \\ Directorate-General for Economic and Financial Affairs}

Number 149

March 2001

\section{A Case for Partial Funding of Pensions with an Application to the EU Candidate Countries}

by

\author{
Heikki Oksanen*
}

\begin{abstract}
Acknowledgements
I am especially grateful to Patrick Wiese of Actuarial Solutions LLC who kindly put at my disposal his Pension Reform Illustration \& Simulation Model, PRISM, which I used for calculating the scenarios reported in this paper. I would like to thank Declan Costello, Kieran McMorrow, András Simonovits and Martin Werding for useful comments on an earlier draft, Cecilia Mulligan for careful editorial assistance and Karel Havik for help in handling data. I am solely responsible for remaining errors and omissions.

Views expressed in the paper are exclusively those of the author and do not necessarily correspond to those of the European Commission, for whose Directorate-General for Economic and Financial Affairs the author is working.
\end{abstract}

ECFIN/192/01-EN This paper exists in English only

* Correspondence: Heikki.Oksanen@cec.eu.int 
(C) European Communities, 2001. 


\begin{abstract}
The paper examines the effects of ageing and makes a case for partial pre-funding of pensions. The argument is based on inter-generational fairness in a situation where pension expenditure as compared to wages increases due to low fertility and increasing longevity. We illustrate the approach by using data representing a typical EU Candidate Country of Central and Eastern Europe with a relatively high pension replacement rate. Pre-funding can take place within the public sector or in a privatised second pillar. We emphasise the need for a consistent framework to cover the many different institutional options available for pension financing.
\end{abstract}

Keywords: Pension system reform, partial pre-funding, ageing JEL code: H5 


\section{Contents}

Pages

1. Introduction 1

1.1. Description of initial conditions in the CEECs 1

1.2. Outline 3

2. The basics of the PAYG and FF systems 4

2.1. Basic arithmetic 4

2.2. The respective merits of the PAYG and FF systems 6

3. Partial funding for inter-generational fairness $\quad 11$

4. Scenarios for a partially funded system 16

4.1. Data and the model 16

4.2. From unsustainable expenditure increase to a new base line 18

4.3. Fairness between generations: introducing partial funding 19

4.4. Administration of the accumulated funds 22

4.5. Partial privatisation 23

4.6. Sensitivity of results with respect to fertility, longevity and interest rates 25

4.7. A note on some previous studies 26

5. Partial funding and privatisation in a broader perspective 27

5.1. Public saving, investment and deficit 27

5.2. Health expenditure 30

5.3. Increased pension contributions and labour market distortion $\quad 31$

5.4. Differences in fertility, family allowances and migration 31

6. Discussion and Conclusion $\quad 33$

ANNEX: Derivation of the formulas for the fair pension contribution rate and pre-funding $\quad 36$

$\begin{array}{ll}\text { References } & 38\end{array}$ 


\section{Introduction}

The purpose of the present study is to examine the ageing problem in the EU Candidate Countries of Central and Eastern Europe (the CEECs). It leads to an argument for partial pre-funding of pensions, within the public sector schemes or in the newly created privately managed pillars.

The argument for partial funding is more general and could be applied to any country with a pension system with relatively high replacement rate and little or no funding. This would include almost all current EU Member States. The present paper is, however, confined to illustrations based on the orders of magnitude typical for the CEECs, and leaves it to further research to apply the approach more generally.

\subsection{Description of initial conditions in the CEECs}

The former socialist system left the CEECs with a legacy of relatively low retirement ages. The statutory retirement age for men was often 60 years, 55 for women, with an effective average retirement age well below these figures.

In the mid-1990s the replacement rates (measured as ratio of average pensions to average wages) were close to or above $60 \%$ in the Czech Republic, Hungary, Latvia, Poland and Slovenia; 40-50\% in Bulgaria, Estonia, Romania and Slovakia; and 30\% in Lithuania.

System dependency rates (pensioners/contributors) were (and still are) high, often well above 50\%, much higher than in the industrialised countries.

In all the countries mentioned, pay-as-you-go (PAYG) pension systems were in operation.

The contribution rates in those countries where replacement rates are high, often topped up by other social security contributions, approached and even exceeded $50 \%$ of wages. ${ }^{1}$

This is only a snap shot of the situation pertaining in the late 1990s. Adding to challenges faced, the ageing of populations as projected in the UN forecast of 1998 presents a far more worrying picture than that envisaged in Western Europe.

Figure 1 depicts the projected development of the old age dependency ratio (OADR), defined here as the ratio of the population over 60 years of age to 20-59 years old, in the 10 CEECs up to 2050 according to the latest UN population forecast. It rises more than the corresponding figure for EU15 on average, still continuing to rise after 2050. The Czech Republic and Poland are depicted as the countries with the highest and the lowest paths among the 10 CEECs.

The figures in Figure 1 are based on the medium forecast, while Figure 2 gives the figures for the high and low population growth scenarios, respectively, for the average of the 10 CEECs. Even in the high growth scenario the OADR roughly doubles its current level by 2050, though in this scenario, fertility rates for most of these countries are assumed to rise to about 2.1 , much higher than their current rate. In the case of the medium and low growth scenarios, the notable feature is that the OADR still continues to rise after 2050, a factor which cannot be disregarded. 
Figure 1: Old age dependency ratio

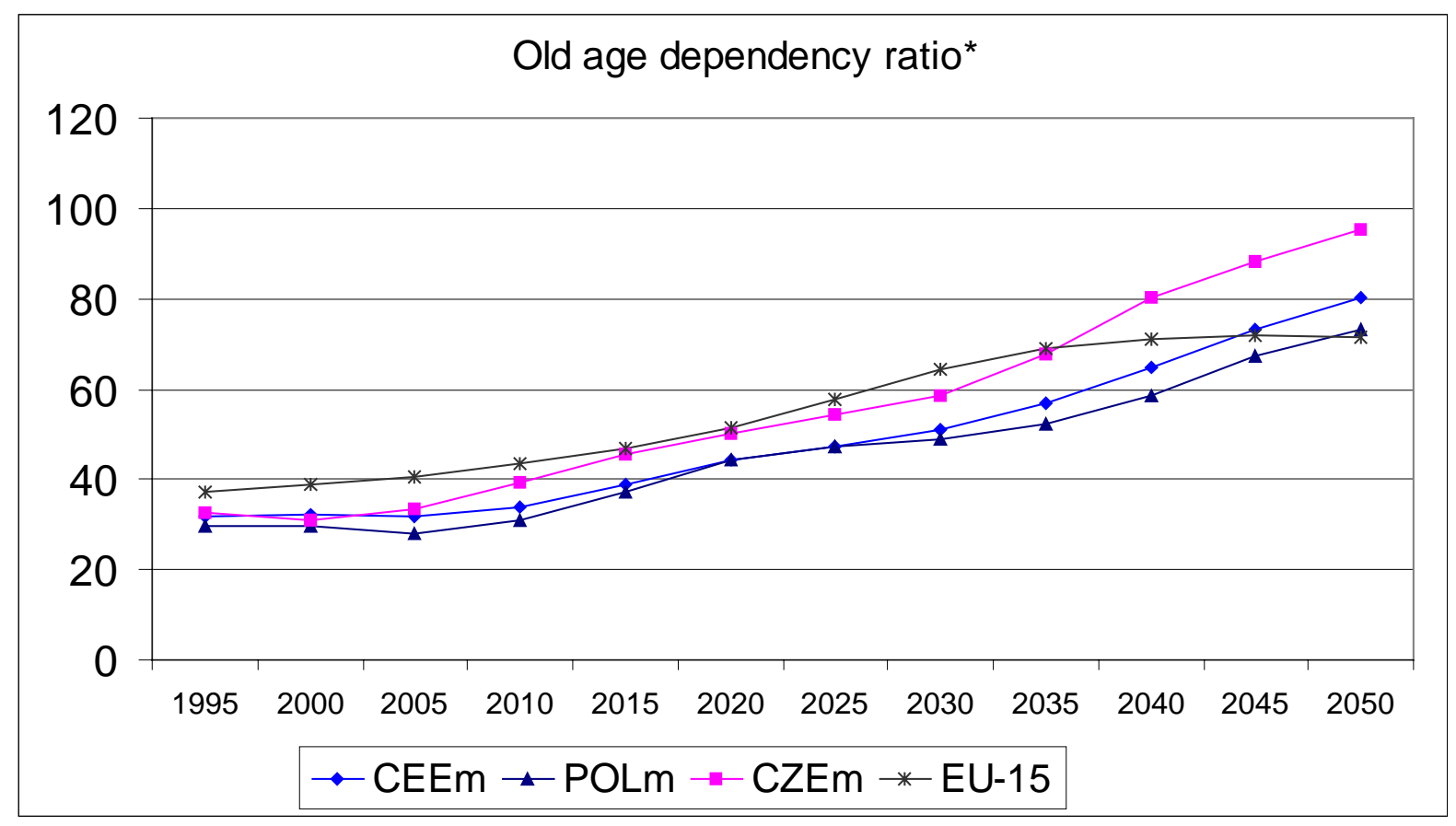

CEEC $=10$ Central and Eastern European Countries $\mathrm{m}=$ medium fertility projection

Source: UN (1998 revision)

Figure 2: Old age dependency ratio

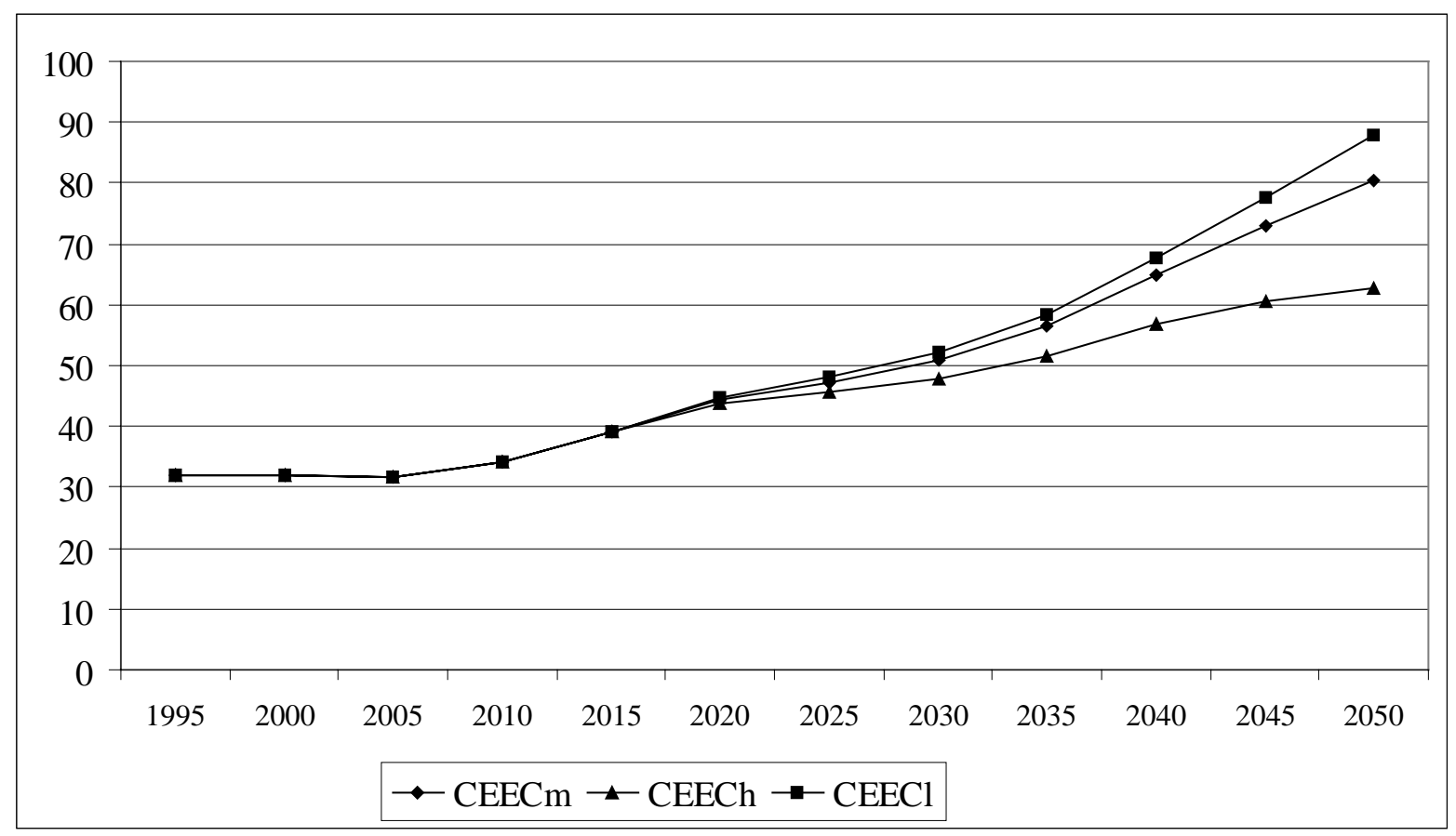

$\mathrm{CEEC}=10$ Central and Eastern European Countries

$\mathrm{m}=$ medium fertility projection

$\mathrm{h}=$ high fertility projection

$1=$ low fertility projection

Source: UN (1998 revision) 
Figure 3: Old age dependency ratio

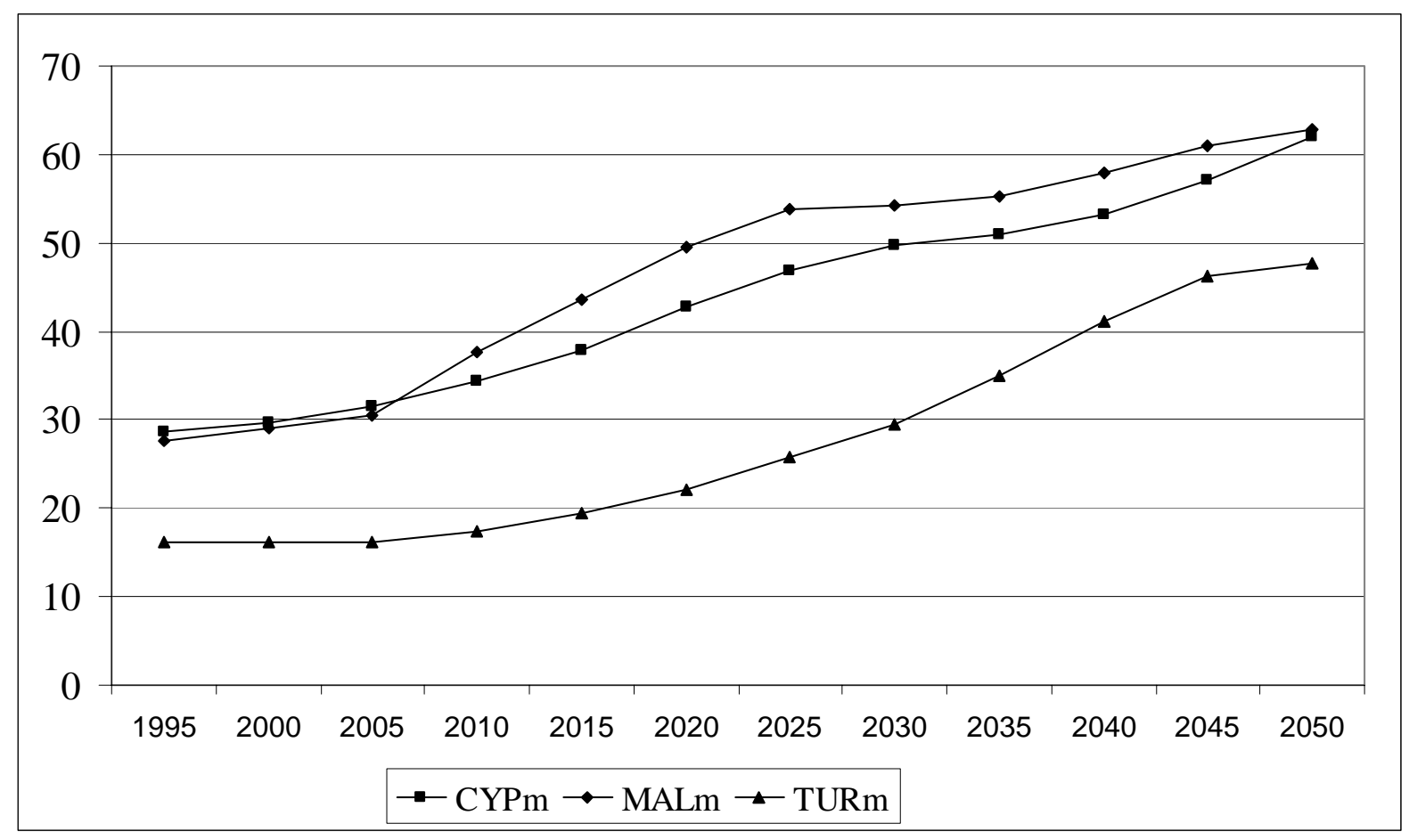

$\mathrm{m}=$ medium fertility projection

Source: UN (1998 revision)

Figure 3 completes the picture with medium growth scenarios for Turkey, Cyprus and Malta. For these countries, and for Turkey in particular, the OADRs are at a lower level, but in terms of projected economic effects, their rise is more significant: for Cyprus and Malta they rise almost as fast as for the CEECs, and even faster for Turkey.

To sum up, in the mid-1990s in the counties with relatively high replacement rates the cost of pensions rose in an unsustainable way, while in others, pensions were adversely hit, causing poverty among the elderly populations. The re-establishment of a social safety net became necessary.

\subsection{Outline}

In Section 2 we review the basic concepts of pension systems and give a short review of the literature of the respective merits of the pay-as-you-go (PAYG) and fully funded (FF) pension systems.

In Section 3 we present an argument for partial funding based on the notion of intergenerational fairness in a situation where pension expenditure as compared to wages increases due to low fertility and increasing longevity. The argument leads to a formula, which rigorously ties the contribution rate and the need for funding to the fertility rate and longevity, producing a simple and easily understandable pension reform rule.

In Section 4 we present scenarios for pension financing using data representing a typical CEEC where the pension replacement rate is relatively high, showing the need for partial funding following from the rule for inter-generational fairness. It is explained that partial 
funding can take place within a public sector administered system or in a partially privatised second pillar.

In Section 5 we analyse partial funding and privatisation in a broader context of public sector finances emphasising the need for a consistent framework to cover the many different institutional options available for pension financing. There, we also make preliminary comments on related issues like health expenditure, labour market distortions and on the effects of family allowances (as a possible determinant of fertility) and migration on pension financing.

Section 6 concludes, giving the general thrust of the present paper for designing pension reforms.

\section{The basics of the PAYG and FF systems}

The objective here is to briefly summarise the very basic concepts needed to discuss pension systems and to give a short review of the literature of the respective merits of the pay-as-you-go (PAYG) and fully funded (FF) systems. The basics are presented with the help of figures that resemble the orders of magnitude in many of the CEECs, or in any country with relatively high replacement rates and high and still increasing old age dependency ratios.

\subsection{Basic arithmetic}

We present the basic arithmetic of pension financing with the help of stylised examples in Tables 1 and 2, presenting for each case figures representing a steady path. More substantive questions related to each mode and to transition from one system to another are discussed in later sections.

We begin by assuming a stationary population, and in the first example, all employees are assumed to work for 35 years and enjoy retirement for 15 years. The replacement rate (pension/wage -ratio) is assumed to be 70\%. This is not particularly high, since in this simplified calculation, in addition to the statutory old age pension for the employee, it also includes the survivors and disability pensions that normally add to costs of old age pensions.

Under these assumptions in the PAYG system, the contribution rate to cover current pension payments is $(15 / 35) * 0.7=30 \%$.

In the FF system the contributors pay a certain percentage of their wages as a contribution which is invested in a fund that earns an interest. Pensions are paid as annuities from the capital and proceeds of this fund. We calculate the contribution required to arrive at a pension of $70 \%$ of the wage (assuming that annuities are indexed to the average wage rate to get a perfect parallel to the PAYG pensions).

For a stable solution the rate of interest must be higher than the growth rate of the wage bill. This difference is most often assumed to be one to two percentage points. For the CEECs, where one expects relatively high growth rates of real wages, this order of 
Table 1. Pension financing: steady path with a constant population

\begin{tabular}{|l|r|r|r|r|}
\hline Active years & \multicolumn{2}{|c|}{35} & \multicolumn{2}{c|}{36} \\
Retirement years & \multicolumn{2}{|c|}{15} & \multicolumn{2}{c|}{14} \\
Replacement rate & \multicolumn{2}{|c|}{$70 \%$} & \multicolumn{2}{c|}{$72 \%$} \\
\hline Rate of interest - w & $2 \%$ & $1 \%$ & $2 \%$ & $1 \%$ \\
Contr. in PAYG & $30.0 \%$ & $30.0 \%$ & $28.0 \%$ & $28.0 \%$ \\
Contr. in FF & $18.0 \%$ & $23.3 \%$ & $16.8 \%$ & $21.7 \%$ \\
F/wage bill & $600 \%$ & $670 \%$ & $562 \%$ & $627 \%$ \\
\hline OADR & $43 \%$ & $43 \%$ & $39 \%$ & $39 \%$ \\
\hline
\end{tabular}

Legend: $\mathrm{w}=$ change of the wage rate

Table 2. Pension financing: steady path with a changing population

\begin{tabular}{|l|r|r|r|}
\hline Active years & \multicolumn{5}{c|}{35} \\
Retirement years \\
Replacement rate
\end{tabular}

Legend: $\mathrm{w}=$ change of the wage rate

magnitude should be sufficient as it maintains real interest rates above the real long term rates in EU-15 (which is a well-based assumption otherwise).

As pensions and the interest rate are assumed to be indexed to the wage rate, the wage rate is taken as the unit of account. Results drawn are thus valid for any assumptions of wage rate movements, real or nominal, or of inflation.

For an individual contributor, the pension fund first accumulates and then goes to zero after 15 years of retirement. At each point in time the fund corresponds to the actuarial value of the acquired pension rights of the employee or the rights still to be utilised by the pensioner. We aggregate over all employees/pensioners and calculate the total amount of pension funds, which is of course constant in a stationary world.

Table 1 gives the key variables as a percentage of the wage bill in both PAYG and FF systems under two alternative assumptions of sharing time between work and retirement, and of the interest rate. The (real) interest rate is either two or one percentage points above the annual change of the (real) wage rate.

Under the above assumptions pension expenditure as a percentage of the wage bill is the same in both systems. It is also, by definition, the contribution rate in the PAYG system. 
Contribution rates in the FF system are considerably lower than those in the PAYG system as the proceeds from the fund make up the difference. Thus, the figures should illustrate clearly how the same expenditure is financed in two different ways in the two cases.

Lower interest rates naturally require higher contributions and a larger fund.

The latter two columns show that an extension of working life, assuming that the employee earns a two percentage point increase in pension for each additional working year, lowers the cost of pensions by roughly seven per cent.

The fund as a percentage of the wage bill varies in these examples between roughly $560 \%$ and $670 \%$. To obtain a rough measure of what these figures mean in terms of per cent of GDP, they should be divided by three for the CEECs and by two for the more advanced economies (EU-15), this difference stemming mainly from the lower ratio of wage and salary earners to labour force in the CEECs.

Note that given the same pension rights in the two systems, the amount of fund in the FF system, which by definition matches the present value of acquired pension rights (of both current pensioners and employees), also gives the implicit liabilities of the PAYG system, also called implicit pension debt, which has to covered by future contributions (for a presentation of this and related concepts see Holzmann, Palacios and Zviniene, 2000).

Table 2 gives the corresponding figures for populations which either increase or decrease steadily by half a per cent per year. Working life is assumed to be 35 years and retirement 15 years. The assumption of the steadily rising or declining population, with the survival rates in each age group assumed to be given, means that the fertility rate is either above or below the 2.1 births per woman, which would keep the population constant.

The first example resembles the growth of populations in the 1950s and 1960s in Europe, while the latter slightly underestimates the ageing problem, as the current and expected fertility rates in the CEECs and EU-15 indicate that populations may well be starting to decline faster than $0.5 \%$ a year. Taking the decline at $0.5 \%$, FF funds or implicit debt in the PAYG system would be around $700 \%$ of the wage bill.

The figures for the contribution rates and especially for the size of the fund under alternative assumptions give a rough idea of the orders of magnitude of key variables and display the internal logic of the two alternative financing systems. We turn next to a comparison of the two basic systems with respect to their various merits and to the much broader issue of transition from one system to the other.

\subsection{The respective merits of the PAYG and FF systems}

Discussion on the respective merits of the PAYG and FF systems has recently been very heated indeed, as top experts have felt the need to clarify their views and arguments. We shall review below the most important aspects and contending arguments.

The cornerstone of analysis and most influential for policy was the World Bank's "Averting the Old Age Crisis, Policies to Protect the Old and Promote Growth", published in 1994. The key recommendation was to create a mandatory, fully funded, privately managed, defined contribution, individual accounts based pillar, which would cover a large proportion of occupational pensions and hence supplement the public 
PAYG defined benefit pillar, which would provide basic pension benefits. A third pillar of voluntary pension insurance, obviously fully funded, would complement the system.

The recommendation for the second pillar - the mandatory FF pensions - later became the object of particularly critical assessments, of which we want to mention four: (1) the UN Economic Commission for Europe Economic Survey 3/1999 containing papers from a seminar in May 1999, (2) Hans-Werner Sinn's paper “Why a Funded System is Useful and Why it is Not Useful" originally presented in August 1999, (3) Peter Orszag's and Joseph Stiglitz' paper "Rethinking Pension Reform: Ten Myths About Social Security Systems" from September 1999 and (4) Nicholas Barr's paper "Reforming Pensions: Myths, Truths, and Policy Choices", IMF Working Paper 00/139 from August 2000.

The criticisms triggered clarifying responses from those who advocate an introduction of a FF pillar, e.g. in a paper by Robert Holzmann entitled “The World Bank's Approach to Pension Reform” from September 1999.

Prior to these recent contributions, differences of opinion were often highlighted by making a comparison of the pure forms of the two systems (and sometimes, as Diamond (1999) put it, by comparing a well-designed system of one kind with a poorly designed system of the other). Thanks to serious efforts by many discussants, many questions are now more clearly formulated and answered, and the reasons behind remaining disagreements are now better understood. Thus, there is now more consensus also on policy advise than a few years ago. The merits of each system have become clearer, and consequently many economists now think that the best solution is a combination of the two systems, where details depend on the institutional environment, notably on the capacity of the public sector to administer a public pension system and to regulate a privately run system, and on the scope and functioning the financial markets. This also means that a lot of detailed work on specific aspects of designing these systems is still needed.

A review of the various points covered by this discussion is worthwhile because setting up a multi-tier system requires that the interaction of its various parts be understood to allow a coherent view of how the entire system works. The purpose is to explain the essential points as briefly and non-technically as possible, while the reviews quoted have easily extended to 20-40 pages. No attempt is made to give exhaustive references to literature as most arguments and long lists of references are found in the papers mentioned above.

\section{A mandatory pension system}

Whether the system is PAYG or FF, we mainly refer to the mandatory parts of pension systems. For the PAYG it is self-evident that a contract between successive cohorts to contribute to the pensions of the elderly in exchange for benefits when the contributor reaches old age has to be enforced by law. In the case of the FF system, this is not equally evident, but the argument shared by most is that it, or some part of it, must also be mandatory to avoid free-riding of those who would not save voluntarily but rather, would expect that in old age the (welfare) state would support them. Once the FF system is mandatory, the state becomes involved in it in various ways, as a regulator and guarantor. 


\section{Defined benefits or defined contributions}

The PAYG system is often associated with defined benefit provisions, which normally means that on top of a minimum amount the pension depends on the wage history of the individual (sometimes up to a ceiling) and, during retirement, on average wage and/or inflation developments. The FF system is mostly associated with defined contributions, where the ultimate pension will depend on the contributions paid by the individual (or his employer on his behalf) and the proceeds of the invested funds.

This dichotomy is not entirely correct as the link between benefits and contributions at the level of an individual in a PAYG system can be made rather tight, if desired, even mimicing a FF system by creating a notional fund with a notional interest rate. Recent examples of this are the reformed Swedish, Polish and Latvian systems, where defined contributions are put into a notional fund with a rate of return equal to the increase in nominal wages. Also, some basically FF systems (like the occupational pension funds in the Netherlands) are defined benefit systems, with contributions adjusted according to earnings acquired (as this can be done only afterwards, it does not work exactly like a pure FF system, but roughly so). Also, if the state guarantees, as it often does, a minimum level of benefits in an otherwise defined contribution system, the system de facto provides defined benefits up to a certain level.

\section{Intra-generational redistribution}

PAYG systems normally include an important element of intra-generational redistribution e.g. a minimum pension level that benefits the poorest. This might be partly neutralised however, by basing the contributions on uniform survival rates for all groups while the low income retirees in reality have a shorter life expectancy.

Advocates of the FF system see it as an advantage that individual accounts help to eliminate redistribution. This may be a valid argument, but one should also note that redistribution can be reduced in the PAYG system by changing the parameters, and that a FF system, if mandatory and therefore state regulated, may also include various elements of redistribution, e.g. by setting uniform parameters for different groups, like gender.

\section{Labour-market effects}

As contributions to PAYG system are often paid by employers and as the link between contributions and pension at employee level is only loose, PAYG contributions are often treated like any other taxes on wages, thus causing a tax wedge between the cost of labour and income received by the employee, and a consequent loss of welfare. One of the most important arguments put forward by advocates of the FF system is that contributions to these funds can be equated with individual savings, thus avoiding any distortion of the labour market.

This dichotomy gives an exaggerated picture. Often in the PAYG system there is also a link between contributions and benefits, though not a perfect one, and it can perhaps be tightened. Furthermore, a mandatory FF system probably also causes some labour market distortion as it covers those who would not willingly save, and because uniform parameters may cause redistribution between different groups (See Sinn, 2000, pp. 400402, and especially Orszag and Stiglitz, 1999, pp. 23-26 for more detailed analysis). 


\section{Administrative costs}

The efficiency of each system depends, among other things, on administrative costs. Not surprisingly, they are considered to be higher in the FF system, and sometimes so high that efficiency can be questioned (Orszag and Stiglitz, 1999, pp. 29-32). Obviously, results will vary between Western countries and transition economies.

\section{Does FF have higher rate of return than PAYG?}

The most important - and the most controversial - argument put forward by advocates of the FF system is that a transition from a PAYG to a FF system increases welfare by improving allocation of capital, in addition to the positive effect via the labour market (point 4 above) net of possibly higher administrative costs (point 5).

For sceptics, this is not so clear. They point out that the difference between the rate of return to accumulated funds in the FF system and the implicit rate of return in the PAYG - which is equal to the rate of increase of the wage bill - has misleadingly been given as a proof of the superiority of the former. Sinn (2000, pp. 391-395) neatly develops the argument that (under certain conditions) this difference only reflects the gains that previous generation(s) received when they did not (fully) contribute to the newly established PAYG system but enjoyed the benefits. These 'introductory gains', as Sinn calls them, led at the time to an accumulation of implicit debt, and the difference between the two rates precisely covers the interest on this debt. The burden is either carried by all future generations or by one or more future generations through reduction of the implicit debt by cutting future pension rights or increasing contributions. Thus, Sinn (2000) shows why the difference in rates of return does not prove the superiority of the FF system over the PAYG (see also Sinn, 1997, pp. 5-8, and Orszag and Stiglitz, 1999, pp. 14-16).

The above argument assumes a uniform rate of return on financial assets. Advocates of FF maintain that transition to funding makes it possible to exploit the difference between returns on equity over bonds. However, this improves general welfare only if the rates of return on capital are generally higher with funding than without, i.e. if real capital as a whole is allocated and used more efficiently. Advocates of the FF system tend to answer this positively, as they believe that pension funds (if properly administered) improve the functioning of financial and capital markets more generally (e.g. by providing liquidity).

Sceptics do not find convincing arguments for improved allocation of capital under funding, maintaining that the distribution of financial wealth between equity and bonds is a separate matter, and that the individual accounts as such do not lead to welfare gains, as one form of debt, the implicit pension debt under PAYG, is merely transformed to explicit government debt.

The advocates of funding note that abstract models of capital markets do not provide an answer, notably in transition economies, where markets are far from perfect and funding could cause shifts in portfolios that involve pension liabilities equal to several times annual GDP (Holzmann, 1999a). They thus maintain that establishing a multi-tier system can increase welfare if properly implemented.

In turn, sceptics may sarcastically ask why, if semi-public funds like mandatory pension funds are a miracle, do governments not borrow regardless of pension financing and create trust funds that contribute to general welfare in the same fashion. 
They may also doubt whether pension funds (where ownership always remains blurred) contribute positively to better allocation of capital or improved governance of enterprises (e.g. Eatwell, 1999, pp 61-62). Interestingly, the said sceptics can come from quite different schools of thought. Some neo-liberals may fear "pension fund socialism", while some Keynesians may suspect that herd behaviour among fund managers causes harmful instability in financial markets.

\section{Each system is exposed to different risks: mixture is optimal}

Both systems have their relative merits in one more respect: the sustainability of the systems as a whole and also individuals in those systems are liable for different types of risks. In short, the PAYG system is vulnerable to demographic risks (i.e. burden increases if ageing shifts abruptly) and political risks, whereby at some stage the young generation may abandon the commitment to pay and leave the elderly without pensions (for a formal analysis see Cremer and Pestieau, 2000).

The FF system is naturally vulnerable to financial market risks (i.e. variations in rates of return that might be affected by any exogenous shocks), but also internally to bad management or outright corruption, a risk that should not be forgotten. It is often asserted that the FF isolates the system from demographic risks. This is true if the rate of return on the funds does not depend on demographic factors. This might be a relatively safe assumption, but in a closer analysis one should recognise that as ageing affects savings, it should also affect rates of interest. Brooks (2000) has produced simulations showing that the baby boom generation loses significantly in the FF system due to a fall in interest rates due to population ageing. The same scenario was produced in a recent Merrill Lynch report "Demographics and the Funded Pension System" (2000).

Thus, although the difference in exposure to different risks might not be so big, it still plays a role, and a mixture of the two systems is therefore probably an optimal way to reduce aggregate risk. The content and relative size of each pillar should then depend on various institutional factors and other details.

\section{The real question: cost of transition to funding and inter-generational fairness}

Comparing the relative merits of FF and PAYG is not sufficient to advocate switching from one system to the other. Moving from PAYG to FF inevitably means that the generation in active service during the transition will pay more than it would if PAYG were continued.

However, this is not a sufficient argument against transition to funding as one purpose for the transition could precisely be to change inter-generational income distribution in favour of future generations. Accepting this, Holzmann (1999a) gives four principal solutions for financing the transition: (1) partial default on promises, (2) use of proceeds from privatisation, (3) controlled debt financing during the early years, and (4) fiscal measures outside the pension system.

Again, it has been said that all this can also take place without individual accounts in the FF pillar. Benefits in the PAYG system can be cut, proceeds from privatisation can be placed in a fund and subsequently used for pensions, thus reducing the required contribution level. For the latter two measures the basic idea is that implicit pension debt is made explicit and then repaid by public sector savings (increased government revenue or reduced expenditure) over a period of one generation or more, as the case may be. 
However, if a public PAYG system is extended to allow deviations from zero balance, then it can also be used to generate savings within the public sector and alleviate the burden of future generations. Orszag and Stiglitz (1999) call this 'broad pre-funding' as distinct from 'narrow pre-funding' under individual accounts. In both cases the current generation "pays twice" (i.e. pays for the pensions of current pensioners and for its own future pensions, or at least partly so).

As a conclusion, although inter-generational redistribution can be affected by a transition from one system to the other, the same effects may be generated by adjusting the parameters of either system. A wider analysis is required for more precise results.

To fully respect the previous literature we should still mention one important aspect that has been debated. It is the question of whether funding, whether it takes place by accumulating a fully funded pillar or within a partially pre-funded PAYG system, has an effect on aggregate savings in the economy, and hence transfers real resources from one generation to another.

Firstly, as to whether private saving decreases as a result of increase of pension funds, the prevalent view is that private savings may react negatively to increased funding, but not to the extent that it would fully offset the positive effect on the saving rate.

As to public sector saving, the answer will depend on gearing the policy more generally. In Section 5 we analyse cases where accumulation of pension funds within or outside the public sector needs to be taken into consideration in assessing public sector saving, deficit and debt.

\section{Partial funding for inter-generational fairness}

The review of previous literature left us puzzled as to the relative merits of each system, and to the desirability of transition from one to the other. If the general result is interpreted as favouring a mixture of the two systems, the question as to how fast and in what circumstances that transition should take place remains open.

In this section we develop a rather simple quantifiable rule according to which fairness between successive generations leads to the need for partial funding. Thus, an aspect that should be inherent in the pension system itself is the driving force, without relying on contestable arguments related to development of financial markets and improvement in allocation of resources or any other aspects outside the pension system.

The starting point is the analysis by Sinn (2000) who shows, as explained above, that the difference between the rate of return in FF and the implicit rate of return in PAYG (the growth rate of the wage bill) as such does not prove that the former is more efficient. This difference stems from the implicit debt that accumulated when the previous generations were given 'introductory gains', i.e. they received benefits while not having (fully) contributed to anybody's pensions themselves. Had the first generation to benefit from pensions first contributed fully, the result would have been a FF system.

Based on this, continuation of the PAYG system can be regarded, says Sinn, as distributing the burden of past introductory gains evenly over all future generations. He considers that the conditions under which this holds are not particularly restrictive, and 
he criticises various arguments put forward for a transition to a FF system. In short, a rapid transition would put a heavy burden on the currently active working population. The fairness of this is questionable (Sinn, 2000, p. 397).

Sinn (2000, p. 402-406) then moves to the demographic roots of the crisis of the PAYG pension systems: normally the working generation pays for old age pensions and for raising children, who in turn pay for the pensions of the previous generation. If the current working generation chooses not to raise as many children as the previous generation did, it is only fair that it pays part of its own pensions by saving now and reverting to those savings when retired, hence easing the burden otherwise put on the following generation, which will be smaller. This is thus an argument for partial funding.

This opening is a useful one. We shall extend it and make it operational by putting numbers on it, deriving easily understandable arguments for partial funding and for its order of magnitude in coming decades.

For the exercise we need a definition of fairness: each generation pays the same proportion of salary to get the same level of pension rights in "similar circumstances", which we explain below.

As already seen, in a steady path (determined by demography and a constant interest rate) both FF and PAYG systems are equally fair.

Let's first remind ourselves that such steady paths may include constantly decreasing or increasing populations. Thus, low fertility per se, and hence reducing population is not a sufficient argument for partial funding. This was illustrated in Tables 1 and 2 above where in all cases, all successive generations pay the same proportion of salary to pensions, including the case with the steadily reducing population.

However, the relevant questions arise when the pension system shifts from one steady path to another. Each such path is determined by demographic variables like fertility and life expectancy, pension system parameters like replacement rate, retirement age etc., and the interest rate. As for the latter, in the simplified world as described in Tables 1 and 2 above, where everything is indexed to the wage rate, it is the difference between the interest rate and the increase of wage bill that matters.

If any of these variables or parameters change, the system departs from the previous trajectory towards another. Depending on the arrangements, some generations may gain or lose. If the system is on a steady path, and any of these factors change, it takes at least 60 years for the system to settle down to the new steady path: this is the time required for a new entrant to the labour force to leave the system (remember that even after his death survivors pensions may have to be paid).

The crux of the matter for the next 50-60 years is that the system is not on a steady path because the demographic factors have changed and are still changing. The burden of pensions will increase particularly rapidly in the next 40 years because fertility has decreased in the recent past and will remain low, and because life expectancy is increasing.

To tackle the question of fairness between generations in a situation characterised by a shift from one (hypothetical) steady path to another, an extension of the concept of introductory gains by Sinn (2000) is useful: under a pure PAYG system, all cohorts that 
paid contributions when burden was lower than what it will be when they retire, get introductory gains. Thus, not only will past and current pensioners have gained from this, but also a large number of currently working cohorts will gain because they retire before the whole system reaches a path of still higher burden. It is only fair to ask whether this is justified, or whether the currently active should now pay in more than what is currently paid to pensioners, thus accumulating funds into a partially funded system.

We shall present a formula for partial funding (technical derivation in the annex) and illustrate it with Table 3 . We assume the following:

The population is composed of children $(\mathrm{E})$, adult labour $(\mathrm{L})$ and retirees $(\mathrm{R})$. The wage rate is taken as the unit of account. Pension is a fixed proportion (p) of the wage rate.

For simplicity we assume that each of the three phases of an individual's life, childhood, work and retirement, are of equal length, which we define as unit period. To keep the correspondence to the real world we assume, firstly, that the unit period corresponds to 30 years, as this is the average age of women at delivery. Secondly, as work and retirement are technically assumed to be of equal length we adjust the replacement rate to make it correspond with realistic numbers: in the illustration we set the replacement rate at $30 \%$, corresponding to $70 \%$ if working life lasts 35 and retirement 15 years.

The interest rate $(r)$ is measured as the excess over the rate of change of the wage rate. In the example we assume that it is $50 \%$ over the unit period, which corresponds to $1.36 \%$ per annum over 30 years.

The population is assumed to have been stationary for at least two unit periods before any change in demographics. Thus in period 0 the number of $\mathrm{E}, \mathrm{L}$ and $\mathrm{R}$ are the same, set at 100 .

With these assumptions in period 0 (with stationary population), the contribution rate $(c)$ required to balance the PAYG system is the same as the replacement rate, $30 \%$. This is taken to provide financing on a sustainable basis.

Then, in period 1 the working population decides to bear $20 \%$ less children than their parents. This corresponds to a decline in the fertility rate from 2.1 births per woman (constant reproduction) to 1.7. All successive generations keep the fertility rate at this new level. From period 3 onwards this leads to a steady decline in the population at a constant rate of $20 \%$ over the unit period, or by $0.7 \%$ p.a.

Scenario 1 in Table 3 illustrates a pure PAYG system if the replacement rate is kept constant. Pension expenditure as a share of the wage bill increases to $37.5 \%$ in period 2 and then stays at that level. This is also the required contribution rate.

In this scenario the adult generation in period 1 would pay $30 \%$ in contributions. Is this fair? Given their decision to have less children their descendants would therefore have to pay $37.5 \%$ of their wages in pension contributions. The working adults in period 1 would 
Table 3. Pension system shifting from a steady state to a low fertility path

Initial fertility preserves a constant population.

In period 1 fertility declines by $20 \%$.

Initial replacement rate $30 \%$.

Interest rate $50 \%$ over the unit period (1.36\% p.a.)

\section{Period}

1 E children

2 L labour

$3 \mathrm{R}$ retired

$4 \mathrm{~W}$ wage bill

$\begin{array}{rrrrr}\mathbf{0} & \mathbf{1} & \mathbf{2} & \mathbf{3} & \mathbf{4} \\ 100 & 80 & 64 & 51.2 & 41.0 \\ 100 & 100 & 80 & 64 & 51.2 \\ 100 & 100 & 100 & 80 & 64 \\ 100 & 100 & 80 & 64 & 51.2\end{array}$

Scenario 1: Pure PAYG, replacement rate constant

$\begin{array}{lrrrrr}\text { 5 P pension expendit } & 30 & 30 & 30 & 24 & 19.2 \\ 6 \text { P/W = contr. rate } & 30.0 \% & 30.0 \% & 37.5 \% & 37.5 \% & 37.5 \%\end{array}$

Scenario 2: Pure PAYG, contribution rate constant

$\begin{array}{llllll}7 \text { Replacement rate } & 30 \% & 30 \% & 24 \% & 24 \% & 24 \%\end{array}$

Scenario 3: Partial funding, new contribution rate 34\%

$\begin{array}{lrrrrr}8 \text { cL=total contributions } & 30 & 34 & 27.2 & 21.8 & 17.4 \\ 9 \text { Interest income } & 0 & 0 & 2 & 1.6 & 1.3 \\ 10 \text { Pension expenditure } & 30 & 30 & 30 & 24 & 19.2 \\ 11 \mathrm{~F}=\text { fund } & 0 & 4 & 3.2 & 2.6 & 2.0 \\ 12 \mathrm{~F} / \mathrm{W} & 0 & 4 \% & 4 \% & 4 \% & 4 \% \\ 1330 * \mathrm{~F} / \mathrm{W} & 0 & 120 \% & 120 \% & 120 \% & 120 \%\end{array}$

Legend: variables on lines 4-5, and 8-11 are measured in wage units.

reap the benefits at the expense of the others, while all adult generations from period 2 onwards would be treated equally amongst themselves, having the same number of children per capita and paying the same proportion of their wages to pensions.

Scenario 2 illustrates a fairer solution. In the pure PAYG system, if the contribution rate is kept constant and the replacement rate decreased correspondingly, the working adult in period 1 receive the same treatment as the successive generations: they get a lower pension because they initiated the decline in fertility. In a typical PAYG system this requires that the accrual rate determining how many percentage points of pension is earned per annum be adjusted downwards according to the decline in fertility. This change should take place already in period 1 .

The decrease in the replacement rate is a straightforward solution to the ageing problem within a pure PAYG system. However, it is not the solution chosen in most countries, as replacement rates are not systematically decreased.

Scenario 3 therefore assumes a constant replacement rate of 30\% and answers the question of how much the adults in period 1 should pay in order to be treated equally with all successive generations. It shows that the fixed contribution rate that must be 
applied from period 1 onwards is $34 \%$. The adults in period 1 pay into the pension system $4 \%$ of their salaries on top of current pension expenditure. This is put into a fund that produces interest from period 2 onwards. The newly created fund alleviates the burden of all successive generations, which all pay $34 \%$ as contributions. The fund as a percentage of the wage bill stays constant at $4 \%$ (or $120 \%$ of annual wage bill, to keep the simple correspondence to annual figures). Full funding in this structure requires a fund of $20 \%$ of the wage bill in the unit period (or $600 \%$ of the annual figure).

Equations (1) and (2) give the formulas for the constant contribution rate ( $c_{n}, n$ for 'new') for all future generations after a change in fertility from full reproduction to $1-s_{n}$ (where $s_{n}$ will ultimately be the rate of decrease of population), and the amount of fund as a proportion of the wage bill $\left(q_{n}\right)$ thus created as functions of the given replacement rate, $p$, $s_{n}$ as defined above, the interest rate, $r$, over the unit period (of roughly 30 years), and the initial fund as a percentage of the wage bill, $q_{0}$. Subscript $o$ refers to the 'old' value until period 0 and subscript $n$ to 'new' value from period 1 onwards. This case is more general than Table 3 in that it allows for an initial fund in period 0.

$$
\begin{aligned}
& c_{n}=p+\frac{s_{n}}{1+r} p-\left(r+s_{n}\right) q_{0} \\
& q_{n}=\frac{s_{n}}{1+r} p+\left(1-s_{n}\right) q_{0}
\end{aligned}
$$

Next, recall that the replacement rate $(p)$ in our simplified calculation is the product of the replacement rate, conventionally defined as the ratio of pension to the wage rate, and the ratio of time periods for retirement and work. The case where longevity increases and the additional time is spent on retirement can be analysed as if $p$ increased. Note that the new values become effective in period 1 if it is realised that those working in this period will live longer, or if it is decided that the replacement rate for them is increased (thus causing in both cases an increase in pension expenditure from period 2 onwards). Equations (3) and (4) give the new contribution rate and the degree of funding, assuming for simplicity a stationary population.

$$
\begin{aligned}
& c_{n}=\frac{1}{1+r} p_{n}+\frac{r}{1+r} p_{0}-r q_{0} \\
& q_{n}=\frac{1}{1+r}\left(p_{n}-p_{0}\right)-q_{0}
\end{aligned}
$$

With the same initial values as in Scenario 3, assuming an increase in longevity such that the time on retirement increases by $10 \%$, gives $32 \%$ as the new contribution rate (instead of $33 \%$ in pure PAYG) and an increase of funding by $2 \%$ of the wage bill over the unit period (or $60 \%$ of the annual wage bill).

The derivation of the more general formulas for the combined effects of simultaneous changes in the parameters is given in the annex.

In deriving these formulas we have made a number of simplifying assumptions, e.g. that there is a uniform, exogenously given interest rate, but this is intentional as it allows us to distinguish the most inherent and important aspects of the pension system from other aspects which merit to be analysed separately. The novelty of the formulas above is that 
they give contribution rates which treat successive generations fairly when one or the other key factor in the pension system changes and the simple properties of a steady path therefore do not hold. They determine the degree of partial funding necessary to carry financing from one period to another so that each generation bears a fair share of the inter-generational burden. Clearly, the formulas also hold for extreme cases like full funding, where change in fertility, for example, does not disturb fairness.

It should be clear from the above that we have defined fairness as everybody facing the same set of key parameters paying the same proportion of her/his wage to pensions. One could explore aspects beyond these parameters and ask whether our definition of fairness is too simple. We leave this, however, outside the present approach with the conviction that, at the very least, our simple and easily understandable definition of fairness gives a benchmark for any more thorough judgements.

With these tools the following section tackles the question of pension contributions and partial funding with a data set that resembles demographic developments in CEECs.

\section{Scenarios for a partially funded system}

\subsection{Data and the model}

Based on the approach developed above, we construct scenarios for pension systems for any country which inherited a high replacement rate and encounters a significant increase in the old age dependency ratio. Most of the CEECs belong to this category.

We have two main criteria in mind when constructing the scenarios: a) the pension system should be sustainable for the next 50-100 years and b) the burden should be shared fairly between the generations as explained in the previous section.

We are using a set of annual data for a typical CEEC, on the basis of which we run scenarios up to 2100 using a actuarial model developed by Patrick Wiese, named Pension Reform Illustration \& Simulation Model, PRISM (Copyright (c) 2000 Actuarial Solutions LLC). The model produces detailed actuarial calculations for pension expenditure and its financing, allowing numerous alternative financing systems. The model captures the cycles of yearly age cohorts, based on assumptions of fertility and survival rates, labour market participation, retirement, pension contributions as percentage of wages, pension expenditure stemming from accrued pension rights etc., just to mention the key features. Based on these assumptions and data for initial variables, the model calculates, for example, pension system revenue and expenditure, the eventual deficit or surplus and implicit pension debt. It is also able to simulate a transfer of part of the contributions and pension rights to a fully funded pillar. Most parameters are changeable, thus the model can be used to run any number of alternative scenarios to analyse the impact of a change of any policy parameter or any demographic or other assumption.

The model captures both the occupational pensions proper and survivors' pensions allowing for alternative benefit formulas. It is detailed in that it contains e.g. labour 
Table 4. Demographic assumptions for the scenarios

$\begin{array}{lrrrrrr} & \mathbf{2 0 0 0} & \mathbf{2 0 1 0} & \mathbf{2 0 2 0} & \mathbf{2 0 3 0} & \mathbf{2 0 4 0} & \mathbf{2 0 5 0} \\ \text { Fertility Rate } & 1.33 & 1.38 & 1.52 & 1.65 & 1.75 & 1.8 \\ \text { Average Lifetime Men after 60 } & 16.4 & 19.7 & 22.0 & 22.2 & 22.2 & 22.2 \\ \text { Average Lifetime Women after 60 } & 21.5 & 24.7 & 26.9 & 27.1 & 27.1 & 27.1 \\ \text { Old age dependency ratio* } & 33.2 & 36.7 & 45.3 & 49.3 & 65.6 & 75.7 \\ \text { * population 60+ over 18-59 years old, \%. } & & & & & \end{array}$

market participation rates and numbers of survivors for each yearly cohort. There is no need to report all such details here as we maintain many underlying features in all scenarios and compare the results with respect to alternative assumptions on a few most interesting variables or parameters.

The model can be used to illustrate developments in the next few decades, with the postWWII baby-boom generation retiring and small age cohorts entering into the labour force. To see clearly the consequences of this we need to simulate at least 50 years ahead in order to calculate the effects of changes in demographics, pension rights and financing modes. We extend the simulations over 100 years, which makes it possible to analyse the convergence to a (hypothetical) steady path and see whether pensions are financed in a sustainable manner, avoiding exploding debt accumulation.

The model is detailed in depicting the pension system, but it is only partial in the sense that it does not cover the interaction of the pension system with macroeconomic variables like GDP per capita growth, rate of interest or inflation. However, this can be considered a strength as in cases where we assume that pensions and all other relevant variables are indexed to wages and simply take the wage rate as the unit of account (as in the previous section). Under this assumption, the results are consistent with any development of the wage rate (or GDP per capita), and therefore powerful due to very wide applicability. ${ }^{2}$ Inflation does not matter for most variables as we assume that pension expenditure is indexed to wages.

The main driving forces are the changes in the two demographic variables, the fertility and survival rates. For fertility rates in 2000-2050 we take a rough average over the CEECs from the latest UN population forecast. The initial values for demographic variables and for the projected survival rates come from Patrick Wiese's data set for Hungary, but as they resemble those of the UN data and forecasts for the CEECs on

2 Thus, throughout the scenarios we assume a simple indexation of pensions to average wages as this helps us to concentrate on the effect of the replacement rate on other variables in a simple and transparent way. In reality indexation is often imperfect, one purpose being a gradual reduction of pensions as compared to wages. One model applied in some countries is 50/50 indexation to nominal wages and price level. In such cases the outcome also depends on the assumed rate of increase of real wages. Furthermore, we should combine the chosen indexation rule with alternative assumptions of the accrual rate, because these two might be inter-related. Three assumptions on these three factors would thus produce 27 different scenarios. The model we are using would allow us to run them, though there is no reason to proceed in that direction in the present paper, where the main question is how fertility and longevity should be taken into account in setting pension contributions and degree of funding. The base case could be any of those 27 combinations, so it is clearly preferable to take a case with a simple indexation rule as the base case to help make the results very general as they are independent of real economic growth. 
average, our exercise is not limited to any individual country. Table 4 depicts the assumed fertility rate, life expectancy at 60 years of age for men and women and the ratio of population over 60 years to that of 18-60 years.

One important set of assumptions concerns participation rates. The model allows the user to assume any rates for each age cohort and make them change in time. In all scenarios to be reported below the participation rates for men aged 30-54 are assumed to increase from a range of $81-90 \%$ to $83-93$ from 1997 to 2025 and then stay at that level, and correspondingly for women from $69-70 \%$ to $75-83 \%$. It is beyond the scope of the actuarial model to endogenise labour market participation with respect to pension contributions or anything else and is therefore left for further studies.

The rate of interest is set by assumption and can be varied. It is assumed to be 1.5 percentage points above wage rate change. While it would be possible to present scenarios with other assumptions, below we merely comment on the order of magnitude of an effect of a change in this particular variable.

\subsection{From unsustainable expenditure increase to a new base line}

The starting point for the scenarios is a balance of the PAYG system in year 2000 with a contribution rate of $35.7 \%$. The accrual rate is 1.65 percentage points per year, which gives a replacement rate of slightly below $60 \%$ after 35 years of service. In addition to old age pensions come survivors and disability pensions. The average retirement age for men is 59.5 and for women 55.5.

A set of three scenarios is illustrated in Figures 4 and 6. Scenario 1 is a 'no policy change scenario' which leads to expenditure at $45 \%$ of the wage bill in 2020 , and over $65 \%$ in 2060. The implicit pension debt in 2000 is $800 \%$ of the wage bill, reflecting not only pensions in disbursement but also the rising expenditure caused by the future pensions of the current work force. The figure increases to over 1300\% in 2050.

The simple conclusion to be drawn from the first scenario is that the contribution rates, given that there are also other taxes on labour income, should be rejected as economically and politically unsustainable. Even with the best controls it would most probably lead to massive evasion of contributions as people would, on good grounds, expect the system to collapse, so incentives to comply with the rules would be weak or absent. (Here we leave aside any arrangements whereby pensions are financed from other sources of public revenue causing redistribution from other groups in favour of employees/pensioners.)

Thus, the conclusion which follows is that the pension rights must be cut in one way or another. In introducing a scenario with reduced pension rights careful thought should be given to whether somebody (or some generation) is losing something. It is true that some, probably most, people will lose as compared to the mechanical historical extrapolation. However, comparing to an illusion of a continuing trend is not very relevant, and a (moderate) cut in pension rights does not necessarily mean that people would lose in comparison with anything that could in reality be possible.

In what follows we do not take a position on what the maximal sustainable level of pension rights might be, but we want to provide a method of moving in steps to arrive at scenarios that could represent a sustainable path. This way we avoid jumping to a scenario of a drastic cut in pension rights without being able to justify it as necessary. If the result of the analysis is that the expenditure is too high for one or the other financing 
pattern, then we should go back and assume a further cut of the pension rights. Again, note that it is the method and the orders of magnitude we want to present rather than any precise numbers.

If the necessity to cut pension rights is the hard part of the chain of reasoning, we want to make the adjustment as softly as possible by assuming that the accrued pension rights are respected and the accrual rates are reduced only for future accumulation of pension rights. This means that expenditure reductions follow only with a lag.

Scenario 2 in Figures 4 and 5 assumes a cut of the accrual rate to 1.25 percentage points. This is a considerable cut, leading to a $44 \%$ replacement rate after 35 years of work. Note, however, that most often the pension is based on the salary of the most recent years before retirement, meaning that the base is higher than the average salary over the entire working life. Also, progressive taxation means that the cut in net pension rights is more moderate than in before tax figures.

Figure 4 shows that the effect of the cut of the accrual rate on expenditure is not big in 2020 , but increases significantly afterwards. Expenditure would still be over $50 \%$ of the wage bill after 2040 showing that it is probably not sustainable.

As another element of reducing expenditure we introduce in Scenario 3 in Figures 4 and 5 an increase in retirement age. We assume that the normal retirement age for men is increased from 60 to 62 , and that the average retirement age increases by 1.5 years. For women the normal retirement age is assumed to gradually increase from 56 to 62 and the average retirement age from 55.5 to 61 years by 2010 . In the model these changes cause a gradual adjustment to participation rates of employees near retirement.

The effect of this cut on implicit pension debt and on expenditure after full adjustment (after 2030) is somewhat over 10\%. It is not bigger because we assume that working longer gives a higher pension. However, in the first years there is an additional transitional impact on the expenditure as workers contribute longer and retire later. In 2010 , for example, expenditure is more than $20 \%$ lower than in the previous scenario.

\subsection{Fairness between generations: introducing partial funding}

For the sake of argument we assume that pension expenditure in Scenario 3 in Figures 4 and 5 can be financed in a sustainable way. However, Figures 7 and 8 show that keeping the contribution rate at $35.7 \%$ does not provide sufficient financing in the long run. True, mainly due to increase of the retirement age, reserves are first accumulated, reaching nearly $100 \%$ of the wage bill, but in 2050 the fund turns negative and debt explodes.

In addition, keeping the contribution rate constant would not necessarily be fair. Therefore, the next step is to find a scenario in which each generation pays in fair contribution amounts with fertility and longevity as forecast (Table 4 above) taken into consideration.

The path for fairly adjusted contributions in Figure 6, Scenario 4, is based on the formula in the previous section. We assume, following the principles of a PAYG system, that at each point in time the contribution rate is uniform for all employees, starting with the 


\section{Figure 4. Pension expenditure}

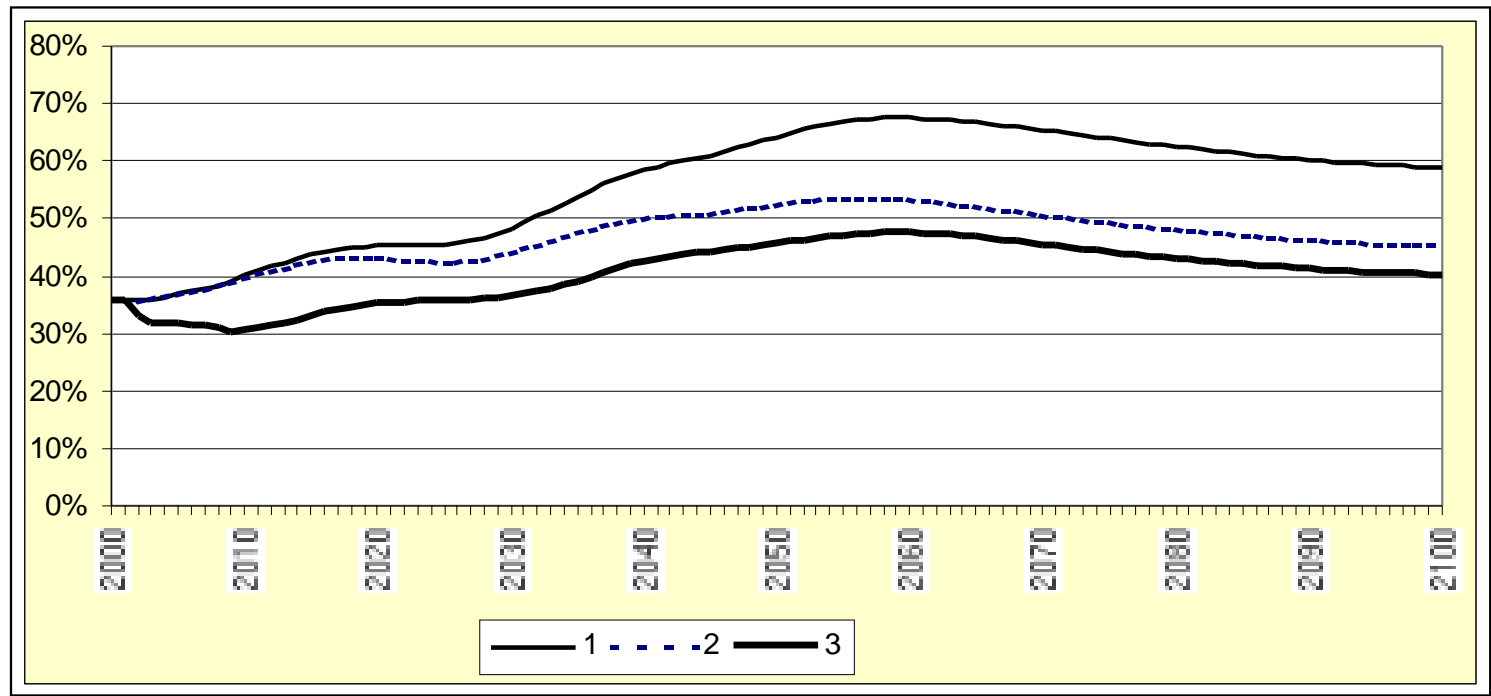

Legend: all figures as a percentage of the wage bill

1. Scenario 1: no reform

2. Scenario 2: accrual rate decreased to 1.25

3. Scenario 3: accrual rate decreased to 1.25 and retirement age increased to 62

\section{Figure 5. Implicit liabilities}

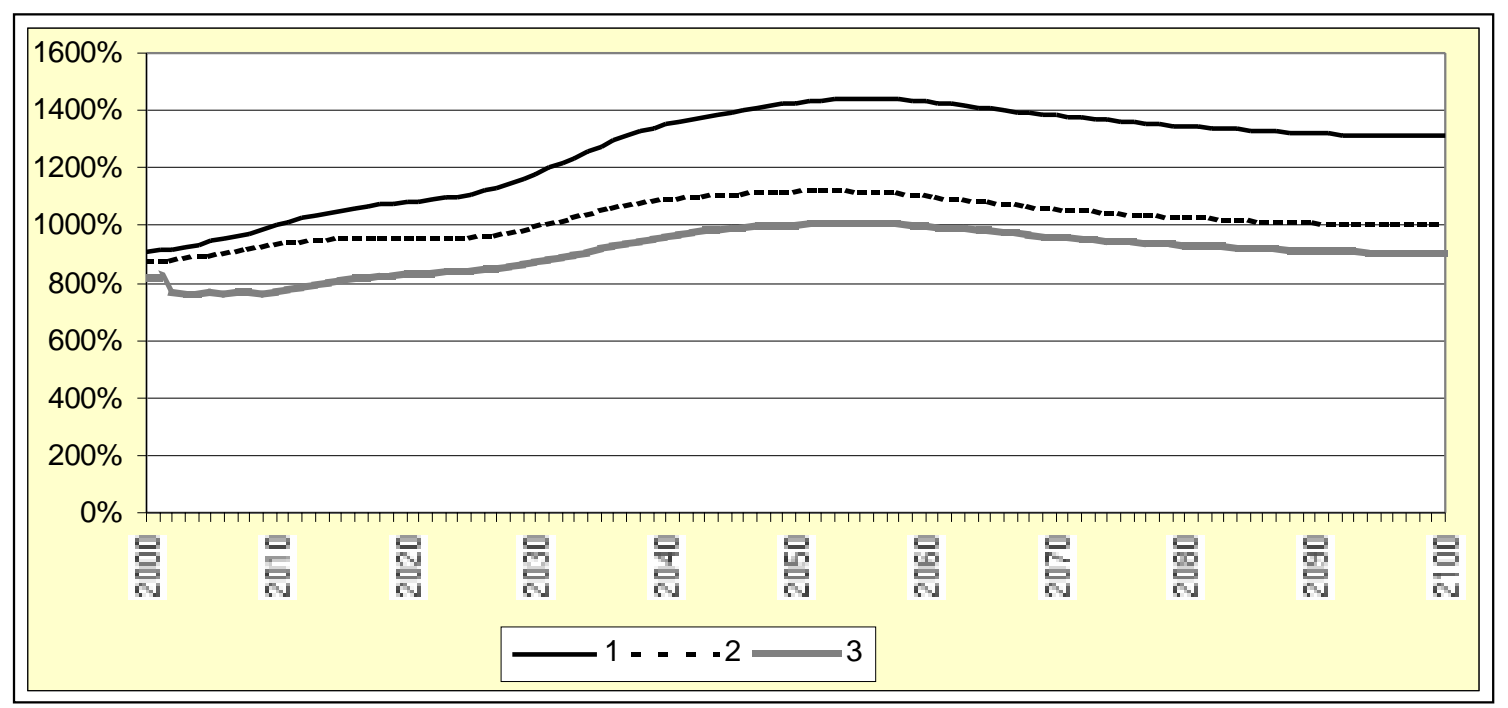

Legend: all figures as a percentage of the wage bill

1. Scenario 1: no reform

2. Scenario 2: accrual rate decreased to 1.25

3. Scenario 3: accrual rate decreased to 1.25 and retirement age increased to 62 
Figure 6. Reformed expenditure with constant and fair contributions

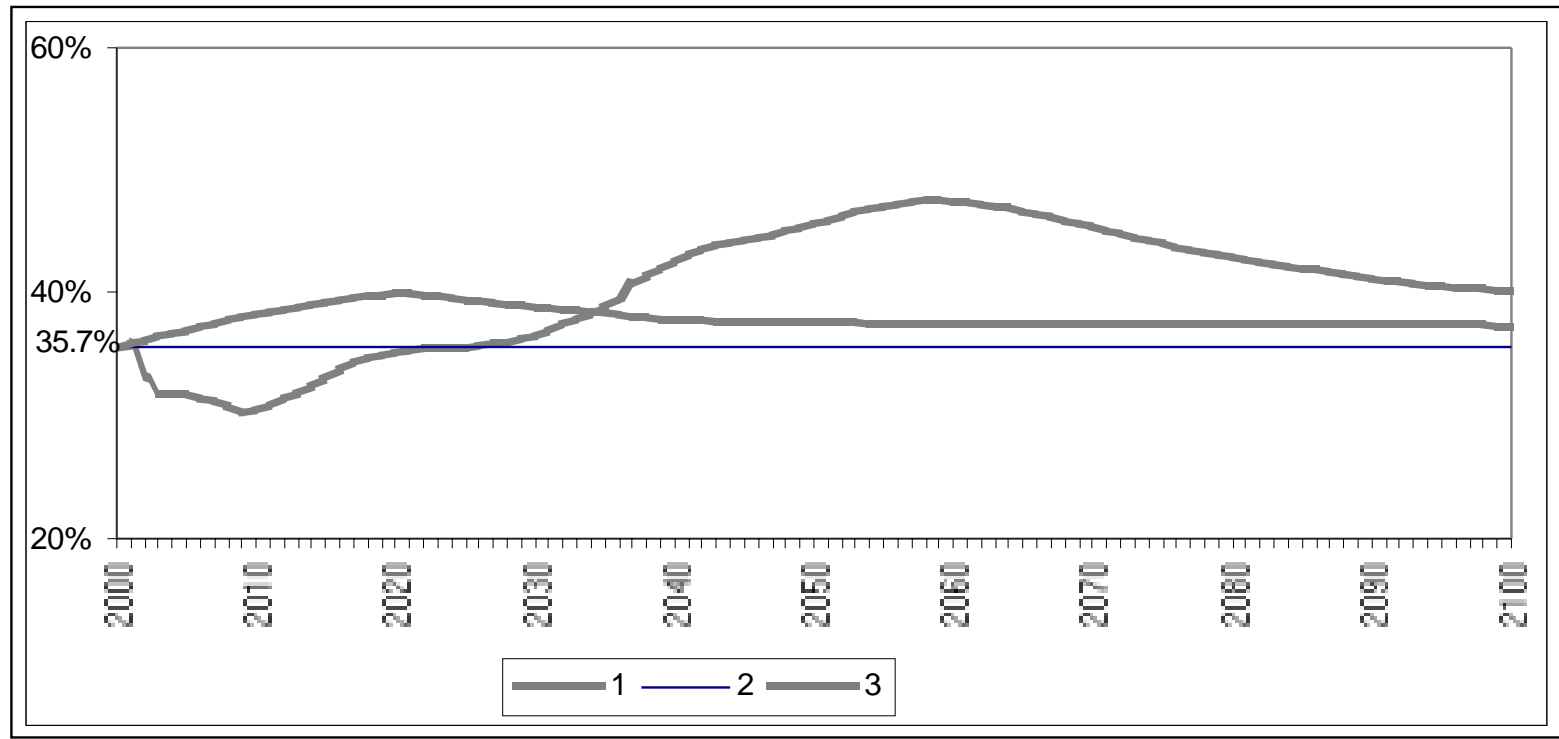

Legend: all figures as a percentage of the wage bill

1. Expenditure in Scenarios 3 and 4

2. Constant contribution rate 35.7 in Scenario 3

3. Fairly adjusted contribution rates in Scenario 4

\section{Figure 7. Reformed expenditure with constant and fair contributions: fund} assets

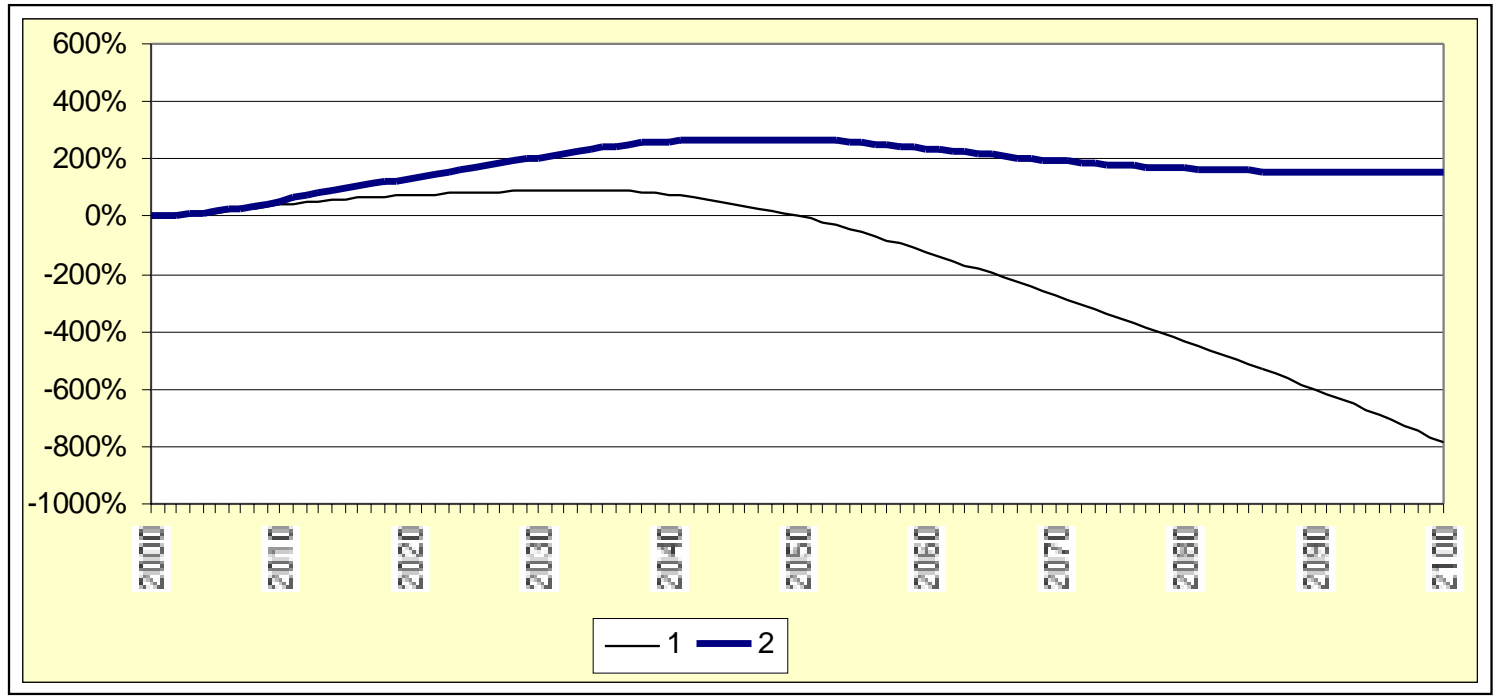

Legend: all figures as a percentage of the wage bill

1. PAYG assets with $35,7 \%$ contributions in Scenario 3

2. PAYG assets with fairly adjusted contributions in Scenario 4 
contribution rate for 2000 . Thereafter, the rate is adjusted according to fertility and longevity. ${ }^{3}$

We see that the peak contribution rate will be just above $40 \%$ in 2020 . Thereafter it will decrease because the effect of increased fertility is stronger than that of increased longevity.

The fund reaches $133 \%$ of the wage bill in 2020, with a maximum amount of around 270 $\%$ in the late 2040s. Due to the assumed increasing fertility of generations active after 2050 and the assumed constant longevity, the fund decreases towards the end of the century.

This amount of partial pre-funding results from a policy to make the generation working from 2000 to early 2030s pay more into the system than the current pension expenditure. Otherwise they would not pay their fair share.

\subsection{Administration of the accumulated funds}

We cover the question of administration of a partially funded public pension system outlined above only from the point of view of explaining whether the funds are classified within or beyond the general government sector in national accounting.

In principle the accumulated fund could be inseparable from any other government assets and liabilities, thus one component affecting government net assets or debts. A straightforward case is that where the accumulated pension funds show as a reduction in government gross debt. This is the case if government gross assets are determined by factors other than those related to the pension system.

For various administrative and political reasons, the public pension system is normally a separate sector within general government. As long as the funds are invested in government bonds, the result in national accounting is the same as above. The limiting case is one where the public, mandatory system is administered outside the government sector proper. There are such cases, with involvement of labour market partners. If the key parameters like benefit rules and contribution rates are still set by the government, these funds are classified as part of general government. Thus their surplus or deficit is a component of the general government financial balance. However, there can be an impact on gross assets and debt. If the pension funds invest only part of their assets in

3 The new rate is calculated somewhat approximately in ten year intervals for the cohort in the middle of working life, looking at past fertility and life expectancy at age 60 . The adjustment in the ten year intervals is assumed to be gradual. 
government bonds and part in the private sector, then gross public debt depends on the shifts between the two. ${ }^{4}$

\subsection{Partial privatisation}

The reform initiatives in many of the CEECs go beyond accumulating funds in the reformed PAYG mono-pillar system by introducing multi-pillar systems with a mandatory fully funded, defined contribution second pillar. Hungary, Poland, Latvia and Croatia have legislated such systems and many others are in the process of preparing such decisions (for a review of pension reforms in transition countries see Lindeman, Rutkowski and Sluchynskyy, 2000).

Typically the new system is established by diverting a certain percentage of contributions to the second pillar. In most cases the oldest employees stay in the old system, those of middle age may choose transition, and the new system is mandatory for the youngest. For those moving to the new system the benefits to be paid from the old system are gradually reduced.

To illustrate the effects of transition to a partially privatised system, starting from year 2000, we take Scenario 4 above as the reference case, assume that total benefits remain unchanged and that a uniform rate of interest prevails for all assets and liabilities. This way we can show the pure effect of partial privatisation on key variables without possible additional effects of the change in the management structure. The transition is assumed to take place by diverting six percentage points of contributions of those who shift to the new second pillar. Half of the contributors are assumed to shift immediately and the rest follow in the two subsequent years.

The result is Scenario 5 in Figure 8, which depicts the main developments in implicit debt of the first pillar (still to be called PAYG pillar as it operates on the same principles as the mono-pillar PAYG system) and the assets of both the first and second pillars.

$4 \quad$ These questions do not arise in most EU countries, which have pure PAYG systems. In Finland and Sweden the question of public pension fund management was deliberated in the late 1950s/early 1960s when partially funded systems were established. In Sweden the funds remained mostly within the public sector. In Finland, to alleviate the fear that the state would use the accumulated funds to take over ownership of production, enterprises were given the right to pay pension contributions on credit (provided that required guarantees were produced), with a scheduled repayment of the debt thus acquired. Until the early 1990s, more than half of the funds were placed this way in the enterprises. Management of the funds was designed so as to prevent domination of any specific interest. Thus, the funds operate outside the state administration under supervision of the labour market partners, i.e. both employers associations and trade unions, closely regulated by the government for the solvency of the system, but without direct interference with investment decisions. - For a description of these Finnish institutions see Lassila and Valkonen (2001). Adding to their information, it might be useful to understand that with the original rules set in the beginning of the 1960s the degree of funding would have been relatively high if there were no inflation. The funds earned a nominal rate of interest and the corrections for indexation of benefits were financed from current contributions. Inflation, especially in 1970s, then led to drastically reduced funds. Subsequently the funding rules were changed in the 1990s to guarantee about $25 \%$ degree of funding irrespective of nominal economic growth. - The Finnish case is just one example of a pension system where the long-run properties were not adequately reflected upon and the rules adopted led to inflation having a perverse effect on the system. 
Figure 8. Partially privatised pension system: Scenario 5

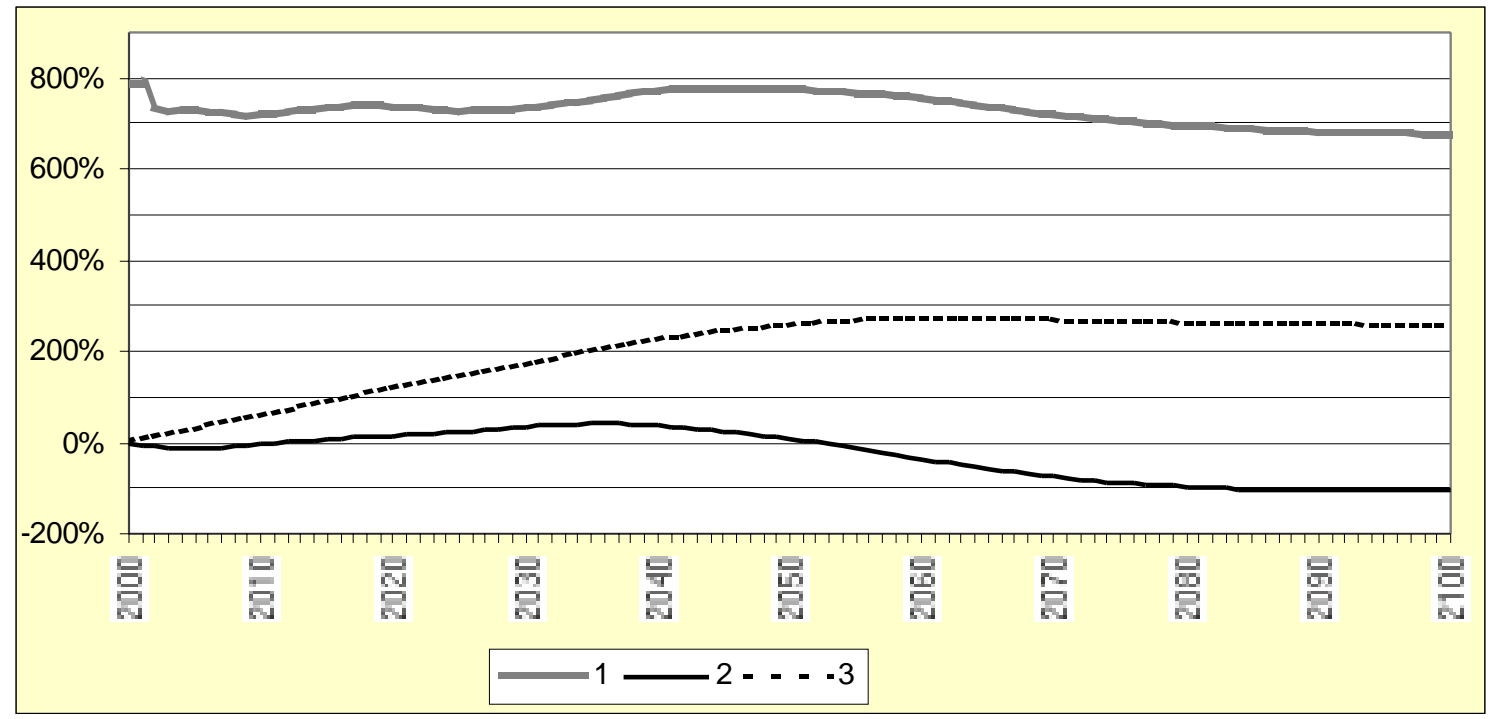

Legend: all figures as a percentage of the wage bill

1. Implicit liabilities in the first pillar

2. First pillar assets

3. Second pillar assets

The immediate effect is that the first pillar goes into deficit of $3 \%$ of the wage bill. Later, as more contributors shift to the second pillar and interest has to be paid on the accumulated debt, the deficit increases further, but subsequently, as part of the benefits are then paid from the second pillar, the deficit declines.

Our reference case has the additional element that it represents a simulation where total contributions exceed pension expenditure in the early decades, therefore offsetting part of the initial deficit in the PAYG pillar. Due to this, the peak of the deficit in the PAYG pillar, $4.5 \%$ of the wage bill (slightly over one per cent of GDP), is passed already in the second year. Thereafter the deficit declines and turns into a surplus in less than ten years. This follows from the surplus of total contributions over pension expenditure, which is highest, almost eight per cent of the wage bill, in 2010. Recall that there are various factors behind this, notably the transitional effect of the increase of the retirement age.

Partial privatisation through creation of the second pillar does not necessarily take place in a situation where partial funding was already foreseen. Therefore, the initial deficit might be a more persistent problem than in the description above. In general, the initial deficit in the PAYG pillar, and hence in the general government, depends on the size of the newly created second pillar, and on the speed of the shift of the contributors. The additional problem is that the speed of transition might be uncertain, depending on the behaviour of the contributors. This causes uncertainty also for the general government deficit, and hence for its use as a target variable in designing the fiscal policy stance.

If a shift to the second pillar is made under a binding restriction on the deficit, there is a dilemma. Assuming that the surplus created in the second pillar will be outside the general government finances, and maintaining the assumptions on pension expenditure, raising the total contributions even more in the beginning of the transition than in Scenarios 4 and 5 above becomes necessary. This raises the issue of too much burden 
being put on the currently active generation. This question would be the more significant the higher the proportion of contributions to be shifted to the second pillar. The extreme case is a transition to full funding where the whole stock of implicit pension debt of 800$1000 \%$ of the wage bill would be repaid by the generation which undertakes this effort. The contribution rates required could easily be seen as unjustly high.

Thus, one has to look into a number of aspects in order to judge whether the shift to the second pillar causes a problem with the deficit and debt of the PAYG pillar, and if so, how big a deficit. We shall return to this issue below in section 5.1.

Scenario 5 in Figure 8 illustrates further how the assets of the first pillar turn positive in 2012 as the second pillar starts to provide part of the pensions and hence reduces the expenditure of the first pillar. Later, its assets again turn negative displaying the longterm pattern that total assets in the entire system are the same as in the mono-pillar case of Scenario 4: as the second pillar reaches its permanent level of assets of 260-270\% of the wage bill the corresponding reduction in the PAYG assets as compared to the monopillar case appears. ${ }^{5}$

Overall, Scenario 5 in Figure 8 should illustrate the short- and long-term phases of shifting part of the implicit liabilities in the mono-pillar PAYG system to explicit liabilities (or to a reduction of its explicit assets as the case might be), and the accumulation of second pillar assets. The initial deficit and the possible emergence of permanent explicit debt as such should not prevent a reform creating a multi-pillar system, but these consequences should be correctly understood in designing the reform and appropriately coped with.

It should be recalled that we have described the transition to a two-pillar system assuming that a uniform interest rate prevails in both of them. If this does not hold, there will be additional shifts in disposable income between the groups covered differently by the two pillars. Of course, the whole idea with the defined contribution second pillar is that its members gain from the rate of return of its assets in the form of higher pensions, but also take the risk of lower return. With the above we sought to show the benchmark case of a uniform interest rate to highlight the pure effects of the transition on the structure of the system.

Furthermore, if there are convincing reasons to believe that the creation and functioning of the privatised second pillar increases the rate of return on capital overall in the economy, general macroeconomic effects would also ensue, extending also to effects on inter-generational fairness.

\subsection{Sensitivity of results with respect to fertility, longevity and interest rates}

One of the key variables determining the fair contribution rates and partial finding in Scenario 4 (and subsequently in the privatisation Scenario 5; Figures 6-8) is fertility. Naturally, its future development is unknown. Fortunately, this is not necessarily a big

5 The consistency of these figures can be confirmed as follows: when approaching a steady path in the late 2100s the total pension debt in Scenarios 4 and 5 is about $900 \%$ of the wage bill. From the orders of magnitude in Table 2 above we know that in the hypothetical case of full funding the contribution rate would be somewhat over $20 \%$. The six percentage point contribution to the funded pillar compared to this is the same fraction as the second pillar assets compared to total pension debt. 
practical problem in applying the present approach for policy. The fertility figure needed to set the contribution rates at each point in time is the average fertility of the currently working population. As most of this population have already passed the fertile age, their rate is already known. For the young adults the expected level should be used in the calculation, and corrections should be made if the outcome differs from the expectation. This way the set contribution rate for each generation would differ only slightly from the ideal one.

As for longevity the decision-making problem is different. The figure to be fed to the calculation of the contribution rate is the expected longevity of an average 45 year old at each point in time. As the forecast concerns the development of longevity for 30 years ahead, errors may occur. As continuing corrections to the forecast can be made, and as the 45 year old would pay the corrected, fair contribution for a further 15-20 years, the effect of the original forecasting error is cut to half.

As for the interest rate assumption - 1.5 percentage points above the change of the wage rate - it is also an unknown variable. If this assumption is not valid but the interest rate is lower or declines (due to ageing or for any other reason as discussed above), then the contributions and partial funding need to be higher than in Scenario 4. For example, it can be inferred from the formulas presented in Section 3 that if the interest rate is $0.5 \%$ above the change of the wage rate, the contributions on average should be roughly 1.5-2.5 higher than in Scenario 4, with also a slightly different time profile.

The sensitivity of results with regard to these key variables, and perhaps some others, can be illustrated with further scenarios, but for the moment we leave it to further research.

\subsection{A note on some previous studies}

There are previous studies that call for partial funding in a system otherwise based on PAYG principles. Some of them, e.g. an IMF study by Chand and Jaeger (1996), specifically tackle the effect of the post-WWII baby-boom generation by proposing accumulation of funds to smooth the effects through temporary funding so that assets would be run down by 2050 .

The basic notion that ageing requires higher contribution rates and funding in the coming decades to smooth the time path of pension contributions in the longer run is apparent in many other studies. For example, Lassila and Valkonen (2000) present such simulations, assuming changes in some policy parameters of a model which simulates the partially funded system in Finland, and shows how the changes affect the distribution of the burden between generations (under alternative assumptions of demographic factors).

The present study deviates from these previous ones by posing the question of intergenerational fairness and by deriving the time path of contributions and funding as a function of the key demographic factors. It leads, firstly, with the prevailing assumptions to a need for permanent partial funding, as permanent as are the demographic factors, the decreased fertility and still rising longevity. Secondly, our approach may lead to such a time path for the contributions that they first increase and then decrease again. This is the case if fertility increases again from the current very low level. Thus, a constant time path for the contributions is not necessarily something to be striven for in all circumstances. 


\section{Partial funding and privatisation in a broader perspective}

\subsection{Public saving, investment and deficit}

Whether partial pre-funding of pensions increases saving and hence transfers resources to future generations is a basic question which cannot be fully answered with a partial model looking only into the pension system. To illustrate the nature of this question we make a deviation to the data on Western Europe.

In Figure 9 we show saving as a percentage of GDP in a sample of 11 EU Member States from 1960-1999, the total for these economies and divided into general government and private sector saving (the figures are for net saving, i.e. gross saving minus depreciation). Figure 10 gives general government net investment and net saving, their difference being general government deficit.

In the 1950s, collective saving in the form of general government saving was in these countries quite commonly $5-10 \%$ of GDP. Then, it was on average normally $2-3 \%$ of GDP until it went negative in 1975, and remained so for long periods at $-2 \%$ to $-3 \%$ of GDP (Figures 9 and 10). General government investment declined fairly steadily, perhaps reflecting decreasing need for physical capital investment within the public sector (note that neither maintenance of physical capital nor education expenditure are counted as investment in national accounts). Thus, movements in public deficit were mostly associated with movements in saving (Figure 10). Private sector saving was rather stable or moved in the same direction as government saving, with the notable exception in 1993-1999 when government saving increased (dissaving reduced).

Combining these observations with the introduction of the (mostly) PAYG pension systems in Western Europe, the following story could be told:

The generation working from 1945-75 generated public savings (most often used to finance public investment, although the form in which capital is accumulated is not important for the argument here). From 1960-90 this generation took back part of those savings in the form of pensions, after having established - circa 1960 in most counties public pension systems (pure PAYG in most countries, with some pre-funding in the Nordic countries). This could be considered fair as they saved so much earlier. The same cannot, however, be said about later developments. Those who entered the labour force after 1970 did not save collectively, but rather, reduced the public sector net assets, and in addition, had far fewer children than their parents. On top of this, they reduced private saving when public saving increased from 1996-99. Yet, - if pure PAYG is continued they plan to make the next generation pay their pensions.

This is not to draw a parallel between the developments in Western Europe in the last 40 years and the EU candidate countries presently, as the situations and economic arrangements are so different in many ways, but we want to draw attention to a minimum set of macroeconomic variables needed to make a consistent analysis.

Our Scenario 4 with fair contributions and partial funding foresees the surplus in a PAYG system rising to over $10 \%$ of the wage bill in 2010, and further to $14 \%$ in 2020 and $17 \%$ in the 2030s. As percentages of GDP these figures are nearly 3\%, 3.5\% and more than $4 \%$. 
Figure 9. Net saving as a percentage of GDP in 11 EU Member States*

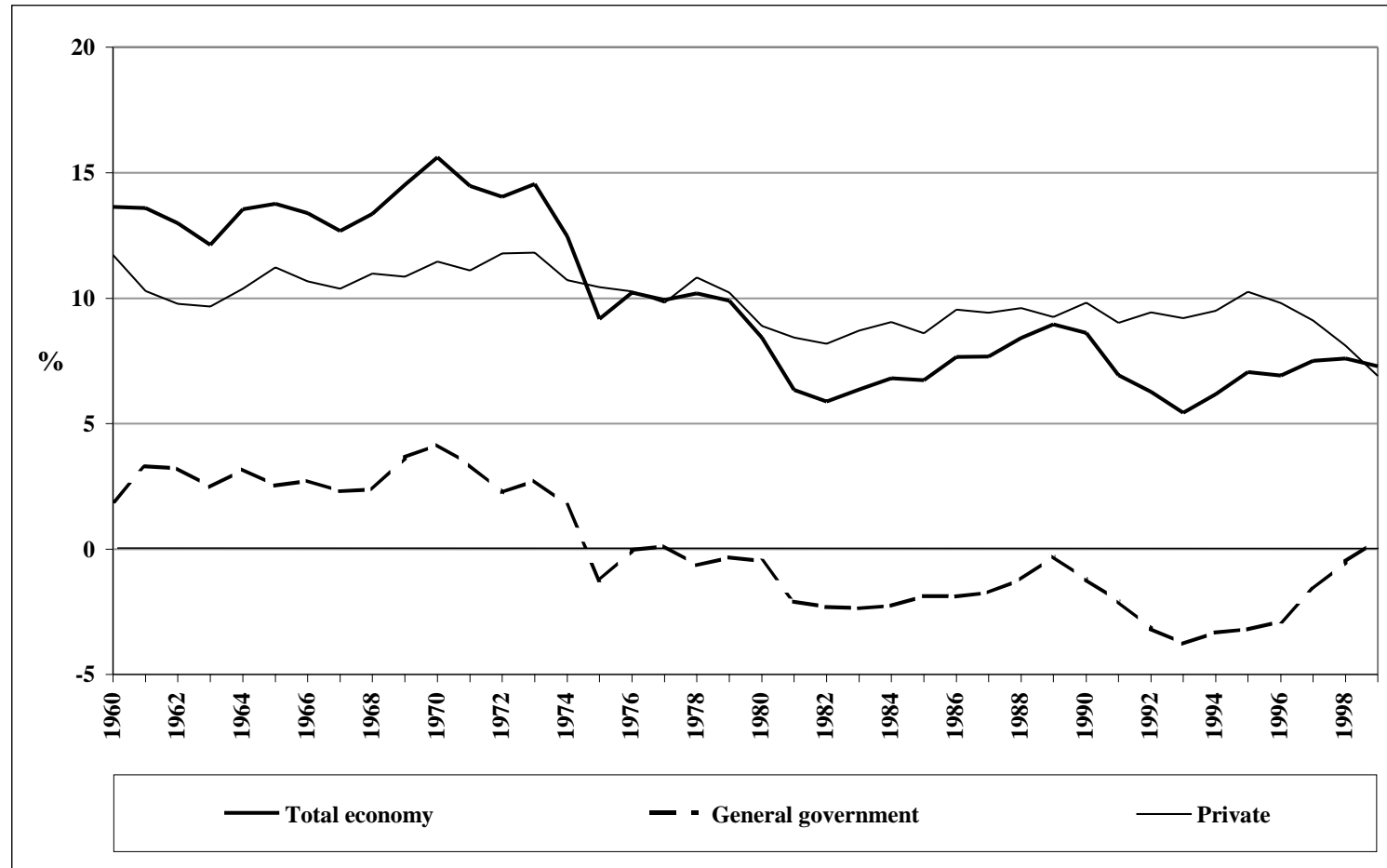

* EU-15 except EL,E,L and S due to unavailability of data

Figure 10. General government net investment and net saving as a percentage of GDP in 11 EU Member States*

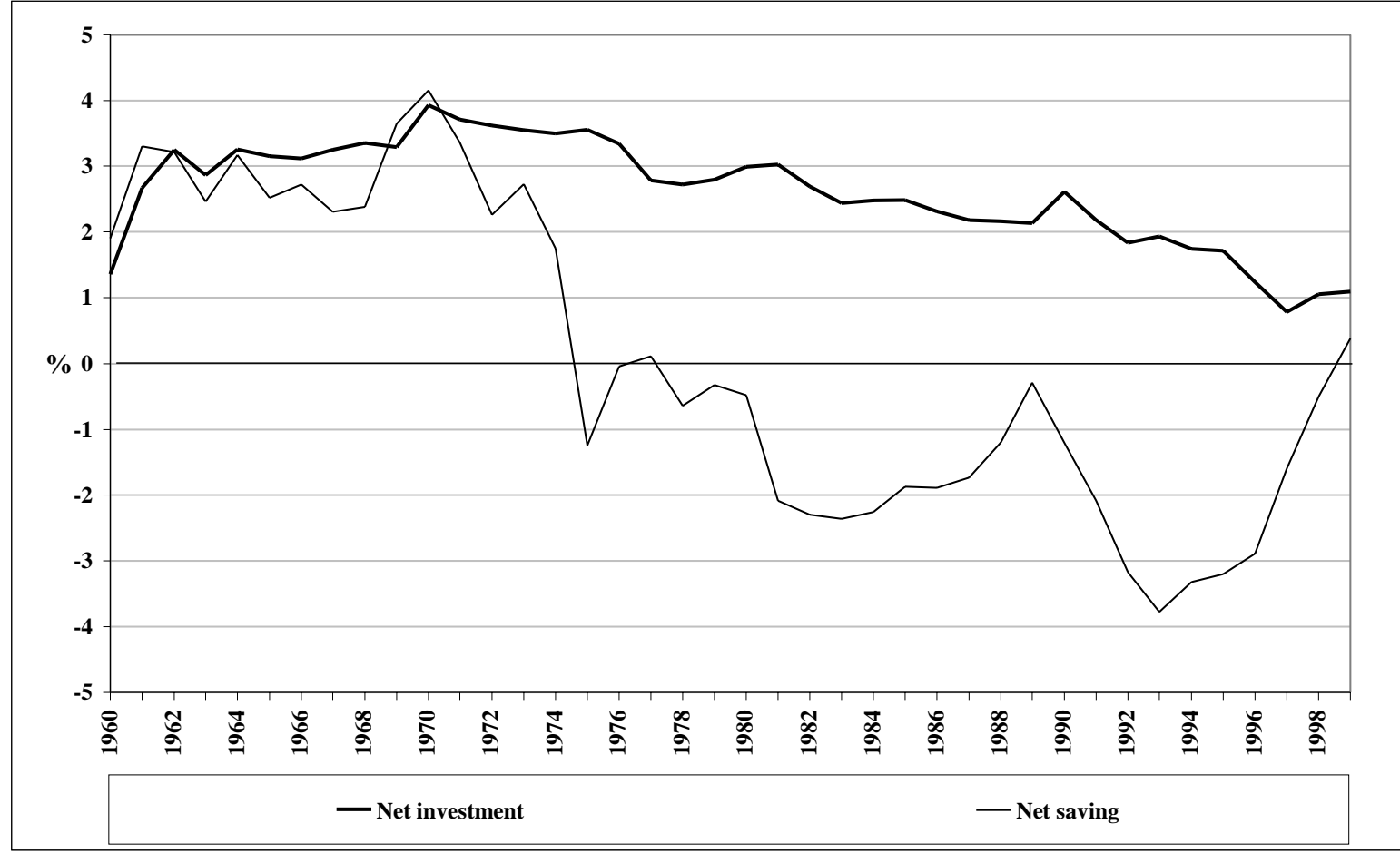

* EU-15 except EL,E,L and S due to unavailability of data

Source: Commission services 
With regard to these numbers we have to make a methodological comment: so far we have analysed and presented figures only for various ratios like contribution and replacement rates, and assets and liabilities in relation to the wage bill, and we have specified an assumption for real interest rate. In our analysis, these figures do not depend on inflation. To present figures for deficit or surplus of the pension system in the conventional sense we need an assumption on the inflation rate as nominal interest rates include an inflation premium (by definition in our analysis). In all our scenarios we assume a gradual decline of inflation from 8\% in 2000 to $3 \%$ in 2006 and onwards. This, combined with e.g. an assumption of real wage growth of $3 \%$ p.a. and real interest rate 1.5 percentage points above that, gives us a nominal interest rate of $7.7 \%$ from 2006 onwards. As this produces the interest income or expenditure of any financial assets and liabilities in our scenarios, the surplus or deficit figures depend crucially on the assumed rate of inflation, leading to higher figures the higher the rate of inflation and vice versa. As modifying the results for other assumptions on inflation would only require a rather straightforward calculation based on the stock of assets or liabilities in the previous year we omit it from the present paper.

We already noted in the previous section that partial privatisation, based on orders of magnitude typical to some reforms in the CEECs, could cause an initial deficit in the PAYG pillar (although only over a few years and perhaps $1.5 \%$ of GDP), a noticeable difference as compared to the surplus created in the mono-pillar PAYG case with the same total contributions and benefits.

As surplus or deficit of the PAYG system, whether it is mono-pillar or the first pillar of a multi-pillar system, is part of general government balance, we next look into alternative cases that may appear when combining pension funding and possible constraints on government deficit.

Firstly, what matters for inter-generational fairness of financing pensions in situations where fertility has declined and longevity increased is collective saving (net of depreciation), whether it takes place within the general government sector or in a mandatory second pillar. Collective saving may or may not be sufficient in this regard.

Secondly, general government deficit, by definition the difference between government net investment and saving, may or may not be constrained by low creditworthiness of the government and/or by a politically imposed ceiling on deficit or debt, or both.

These two factors produce four possible combinations:

1. Sufficient collective saving \& restrictions on government deficit not binding: more likely if mono-pillar PAYG were partially funded. To keep the economy on a sustainable long-run path attention needs to be given to sufficiency of public investment and ambitious enough targets for general government surplus.

2. Sufficient collective saving \& restrictions on government deficit binding: more likely if government investment is high or if a transition to a partially privatised pension system is underway. Pension fund privatisation may have a harmful effect on government investment or lead to excessive burden on the current generation (if the resulting public deficit is rapidly reduced). Can also lead to postponing privatisation of the pension system. 
3. Insufficient collective saving \& restrictions on government deficit not binding: low deficit likely to be a sign of low public investment and general stagnation. Take-off requires general policy measures. Increased pension funding could be a welcome addition to financing the reviving investment.

4. Insufficient collective saving \& restrictions on government deficit binding: increased pension funding instrumental in getting the economy to a sustainable long-run path. Restriction on deficit could lead to postponement of pension system privatisation.

Partial funding within a mono-pillar PAYG system would hardly be harmful, no matter what the circumstances. A pension reform clarifying the rules as regards distribution of the pension burden between successive generations as understandably as possible, could be useful in that it would provide a framework for separating pension decisions from other fields of both public and private economic decision making. Even in an extreme case where collective saving is already sufficient to transfer resources to future generations, increased funding is not necessarily harmful as saving can be correspondingly decreased in other parts of the public sector.

The problem cases are those where partial privatisation may lead, under government deficit already at a critical level, to harmful reduction of public investment or excessive saving. Whether this is likely to happen will depend on the speed of privatisation, the desired level of collective saving and the content of the possible restrictions on public deficit. For these cases, it would be useful to establish rules to look consistently into saving within the pension system as a whole, including both the public sector pillar and the mandatory privatised pillar in order to solve the conflicts between competing targets.

\subsection{Health expenditure}

The approach presented in this paper can be extended to other age-related public expenditure besides pensions. The closest and quantitatively important item is health expenditure. No attempt is made here to analyse it in detail. We mereley note the basic principle and give a very rough estimate of the order of magnitude.

In EU-15 health expenditure is roughly one third of pension expenditure, and about $40 \%$ of it goes to those aged over 65 years (McMorrow and Roeger, 1999, p. 17). In the CEECs the proportion of public health expenditure of GDP is roughly the same as in EU15 , though more detailed data on its structure is not available for the present study.

Health expenditure does not necessarily grow proportionally to longevity as people may stay healthy for longer than before and as a significant proportion of health expenditure is consumed in the final months of life. Yet, rough estimates show that it grows at least almost proportionally to ageing. Thus, as a first approximation, the figures representing the rise of pension expenditure due to ageing need to be scaled upwards by about one third if one wants to take into account the increase in health expenditure.

More specifically, if health expenditure is part of general government expenditure, then the target for general government saving in the next decades should be increased in the same fashion as for pension expenditure. With the figures for Scenario 4 above, the targets for public saving by 2010 and 2020 should be $4 \%$ and $4.5 \%$ of GDP instead of $3 \%$ and $3.5 \%$. 
If part of health expenditure is met by mandatory private-sector managed insurance, regulated by the public sector authorities, then the arguments related to privatisation of pensions applies, mutatis mutandis, leading to the conclusion that reserves should be accumulated in those insurance schemes.

\subsection{Increased pension contributions and labour market distortion}

As compulsory pension contributions cause a labour market distortion of some degree the increase of contributions required for pre-funding will initially aggravate this problem. This is not, however, a sufficient reason to dismiss pre-funding, as one should analyse this with a time perspective covering the future generations which would benefit from pre-funding.

In implementing the policy of increased pension contributions over the next 30-40 years one should also consider the structure of taxation more generally. If there are other taxes on wages and if the revenues are used for purposes other than those directly linked to work and employment, perhaps they could be reduced and replaced by other taxes in order to make room for an increase in pension contributions. This would keep the labour market distortion unchanged or reduce it, as pension contributions, if properly based on a consistent framework of inter-generational equity, could be linked to pension benefits in an understandable and commonly accepted way. If the link between the contributions and benefits is made clear in a modified PAYG system with pre-funding as necessary, the labour market distortion need not represent a much bigger problem than in a defined contribution fully funded pillar.

As to the sustainable level of pension contributions, no fixed view is taken in the present paper. The starting point in the scenarios was the $35 \%$ contribution rate, which is currently common in many CEECs. Our argument was that a 50\% and subsequently even $60-70 \%$ contribution rate required to balance the books of a pure PAYG system, with no change made in policy, is not sustainable. Thus, we argued that benefits need to be cut and retirement age increased. We produced a scenario with pre-funding where the contribution rate would increase to $40 \%$. It could be sustainable, if it held for the current $35 \%$ rate, especially if the link between contributions and benefits becomes tighter and well understood. If it turns that the $40 \%$ contribution rate is not sustainable or if it is unacceptable for any other reasons, then the conclusion should be to cut the benefits further and/or increase the retirement age. To keep contributions low and maintain the benefits would not be fair vis-á-vis the future generations.

\subsection{Differences in fertility, family allowances and migration}

Recall that in the scenarios above we assumed that at each point in time the contribution rates are uniform for all employees. We also noted above that unexpected changes in fertility do not represent a big problem as changes are observed already in the early stages of working life.

In principle, different contribution rates could be set for different age cohorts according to their fertility, thus deviating from the basic principle of a uniform contribution rate in most PAYG systems. Whether there are strong arguments for this, taking into consideration other desired or undesired redistributive features in the public pension system, we do not address here. 
Another aspect in fertility focused pension financing is intra-generational redistribution according to the number of children. In the above approach, the generation was collectively set to bear the consequences of declined fertility, with no attempt to look into factors affecting fertility or distribution of burden between those with many children and those with few or none. However, these issues might be inter-related as most welfare states give financial support to child care, basic education etc., financed from tax revenues, which may affect fertility. This way, those who have no children (or only one) support larger families, and alleviate the negative consequences of ageing. Looking into this mechanism could be an extension of the present approach, which is confined to the distribution of the pension burden between successive generations collectively, given the changes in demographic factors.

Migration is another source of change in age structure and population size. It has even more rapid effects than changes in fertility as migrants leave or enter the labour force immediately. Without attempting a full coverage of its effects, we make a couple of observations on the basis of the approach presented in this paper.

Firstly, if net emigration takes place from the CEECs and if emigrants are in the early stage of their working life, the effect is most likely a negative one, much like a decline of fertility. The special comment that stems from the above analysis is the following: if the emigrants take the accrued pension rights with them on an actuarial basis (as they would do on the basis of EU legislation) and if the contributions did not reflect the future burden properly, then the loss due to emigration is even greater than in a case where contributions fairly reflected future expenditure. Thus, in this case, those who stay have to bear the rising burden, and face the question of whether sharing it between the current and future generations is fair. - Transferring the fully funded part of pension rights is simpler and does not generally cause a problem of fairness.

Second, assume that economic growth occurs in the CEECs, and that consequently more immigrants from further east and south arrive than those who emmigrate to Western Europe. In this case we need to assess the widely held notion that immigration is a factor alleviating the pension burden in an otherwise ageing society: the immigrant workers add to contribution payments, thus allowing lower contribution rates than without migration.

This is naturally true in a sense, especially in a short and medium run, but the present approach adds another angle. One should note that the alleviating effect on pension financing is only the first effect. When the migrants retire, their pensions have to be paid. If the currently active reap the full effect of rising number of contributors by reducing the contributions rates, ceteris paribus, as would happen in a pure PAYG system, then the burden is shifted to future generations. If this is considered to be unfair, the rise in contribution payments due to migration should be put into a fund, which would depending on later developments - possibly become permanent and produce interest income to be used for pensions of all future generations (see Sinn, 1997, for an analysis of the value of an extra child and an immigrant as a basis for a differentiation of pension contributions according to the number of children and making a distinction between incumbent population and migrants). 


\section{Discussion and Conclusion}

In this paper we have presented an approach and a formula to determine the need for pension pre-funding in a situation where fertility has declined and remains low and longevity increases, causing a noticeable increase in the old age dependency ratio. This is the situation not only in all industrial countries, but especially in transition economies. The pressure thus put on pension systems is more marked in those counties where public pension systems are relatively generous. Most of the EU Candidate Countries belong to this category.

Shifting the increased burden to future generations would not be fair and perhaps even not feasible as the system might break down under rapidly rising expenditure and contribution rates. We found that in a typical CEEC with a relatively high replacement rate there is most probably a need to cut the future accumulation of pension rights and to increase the retirement age to get pension expenditure to an order of magnitude that could be financed in a sustainable way. To cope with inter-generational fairness we derived a simple formula for determining the need to raise pension contributions above the level of current expenditure in the coming decades so as to accumulate funds, which would later alleviate financing of pensions by providing the interest revenue to complement contributions paid at each point in time.

We showed that, for a typical CEEC, dividing the burden of a moderately cut pension expenditure in a fair way between generations leads to an accumulation of funds up to nearly $300 \%$ of the wage bill by 2040 . Thus, the choice of whether or not to pursue this line of policy and if so, how to manage these funds, is perhaps one of the most important areas of public policy.

Our formula for pre-funding is based on a simple notion of fairness: if fertility, the total retirement income (the latter being a product of the expected time on retirement and the replacement rate) and the rate of interest are the same, then successive generations should pay the same proportion of their salaries in pension contributions. If these factors differ between generations, then the contribution rates should differ correspondingly. The formula shows what each generation should pay so that each bears a fair pension burden. It shows that this holds under the pure PAYG system only under specific conditions of steady development, which definitely do not hold now, and will not hold in the next few decades in most European countries, to name but a few.

Given the prevalent demographic factors and replacement rates, the fair contribution rate - as derived from the formula - may be found intolerable for a variety of reasons, e.g. because it is thought that the increased contribution rate causes an distortion in the labour market as employees do not understand the contribution payment as saving for pensions but as a simple tax. This may be the case, but we should note that leaving the contributions lower without cutting benefits would only shift the problem to future generations, and that the distortion effect probably widens, even relatively. Thus, if the required increase in contributions is intolerable, the fair solution would not be to leave the future generations to pay more but rather, to cut the (accumulation of) pension rights of the currently active.

One could go deeper into the ethics of fairness, e.g. by asking whether it would not be fair that future generations pay more for similar benefits if their income level were higher (due to technological progress and/or accumulation of capital). This is a fair question, but it is not easy to see whether it means that the formula should be modified substantively. 
We feel that the simple notion of fairness adopted here is a useful one in that it at least provides an easily understandable benchmark, though obviously further development of these ideas could provide a useful refinement to it.

The basic approach applies to a PAYG system, and it shows that, at least in principle, pre-funding can be fed into it. Administration of the accumulated funds is a separate issue, wide open for many different solutions while keeping the funds within the public sector. For various institutional reasons it is often considered wise to administer the pension funds under special institutions so as to guarantee long-run stability of the system by preventing arbitrary political interference. Privatising part of the system is then one ultimate solution, which has created interest in many of the CEECs.

Whether or not part of the pension system is privatised, the sustainability of the system as a whole, including its public and private tiers, remains to be secured. Some authors have drawn attention to benefits of flexibility in funding rules (see Orszag and Orszag, 2000). In a certain way we share that view by presenting an approach where funds are accumulated within a basically PAYG system. However, we would put the emphasis on the need for clear and persistent rules to be followed rather than on flexibility: the formula derived above provides a rule for setting the contribution rates; if the underlying variables change, contributions should also change, but this can be done in a transparent and understandable manner - this is useful if one believes that it helps to take decisions with long-run consequences in a democracy. The formula provides a middle way in the discussion on PAYG and full funding by providing an argument for partial funding, but also showing that too fast an accumulation (e.g. by fast privatisation) might not be fair for the current generation, and hence be politically unsustainable.

We have argued above that in most cases accumulation of pension funds in any form really transfers resources for future, thus behaviour in either public or private sector or both do not undo, at least not fully, its real effects. The commonly held view is that it normally does not. We may add that even if it did so partially, it is probably useful to set clear rules for an area of public policy as important as pensions and help to separate it from many other public policy decisions with a shorter time perspective. This calls for, among other things, a consistent analysis for setting the targets for general government deficit and debt in the short, medium and long run.

* $\quad * \quad * \quad * \quad * \quad * \quad * \quad * \quad *$

We have repeatedly pointed out critical stages in the argumentation which require further assessment. The approach is partial in the sense that it is based on actuarial calculations covering only the pension system. Some of the questions to be encountered in designing a pension reform will perhaps require analysing the links between the pension system and saving and investment in the various sectors, which requires a more general macroeconomic model. But it is probably also legitimate to say that for such an analysis to be operational one needs a detailed enough picture of the pension system, at least along the lines of the actuarial model used in this paper. In fact, the actuarial calculations should - and could - be made more detailed to better fit the specific circumstances in any given country.

One simplifying assumption in the above is that in each scenario pension expenditure is assumed to be indexed to wages once the entry replacement rates are determined by the accrual rates. This may not be exactly true to real world pension systems but this simplified approach allows us to concentrate more clearly on distribution of income 
between the currently active and pensioners without being obliged to consider many possible combinations of alternative indexation rules and assumptions of real economic growth and inflation.

One of the main consequences of a close relationship between pensions and wages under each set of pension system parameters is that it emphasises the fact that economic growth as such does not solve the problem of ageing. If real wages increase, pension expenditure normally also increases, and leaves unresolved the problem of rapidly rising contribution rates in the coming 30-40 years required to balance the PAYG systems, as is largely the case in the CEECs and also in EU-15. Thus, one should not rely on prospects of accelerating economic growth, but cutting future accumulation of pension rights, increasing the retirement age, and partial funding in the coming decades should be seen as necessary for putting pension systems on a sustainable path and for being fair to future generations. Having said this, we can accept that if more rapid economic growth alleviates the making of these changes, then it will have a positive overall effect. If, in addition, the suggested partial funding boosts economic growth, there is then an extra benefit, but the argument for partial funding holds also without it.

It is important that difficult and complicated questions of public policy be presented as clearly as possible, to emphasise the role of the most important factors. This is especially challenging in the area of pension reform where the time horizon goes well beyond what people commonly envisage. It is in this spirit that we have presented results of a actuarial model concentrating on the key features of the pension system.

The approach presented above - illustrated with scenarios for a typical CEEC - should provide a framework for pension policy decisions based on a consistent set of rules to be followed when demographic factors change, as foreseen or unexpectedly as the case might be. This is important as the consequent changes in pension system parameters should not look arbitrary. Otherwise lack of public support might make the economically required changes politically unfeasible. 


\section{Derivation of the formulas for the fair pension contribution rate and pre-funding}

The population is composed of children $(E)$, adult labour $(L)$ and retirees $(R)$. The wage rate is taken as the unit of account. Each of these phases of an individual's life are of equal length, which is set as the unit period.

Fairness means that all future generations are treated equally with the generation active when a change in any parameter takes place.

Parameters with subscripts $o$ refer to values until period 0 and with subscript $n$ to those from period 1 onwards.

The replacement rate $(p)$ captures both the replacement rate proper and the time spent on retirement (affected by a change in longevity. Note that the new value becomes effective in period 1 if it is realised that those working in that period will live longer, or if it is decided that the replacement rate for them is increased (even though in both cases an increase in pension expenditure starts from period 2 onwards).

The parameters are:

$c=$ contribution rate,

$p=$ replacement rate

$s=$ parameter such that $1-s$ indicates the number of children per adult labour (on a steady path population decreases at a rate of $s$ ),

$q=$ assets of the pension fund as a proportion of the wage bill, and

$r=$ rate of interest over the unit period.

It holds

$$
\begin{array}{ll}
R_{t}=L_{t-1} \quad \text { for all periods } \\
E_{t}=\left(1-s_{0}\right) L_{t} \quad \text { for } \mathrm{t} \leq 0 \text { and } \\
E_{t}=\left(1-s_{n}\right) L_{t} \quad \text { for } \mathrm{t} \geq 1 .
\end{array}
$$

Any of the parameters $p, s$ or $r$ may change in period 1 . For period 1, total revenue of the pension system (contributions and interest income) is equal to pension expenditure and accumulation of funds, thus

$$
c_{n} L_{1}+r_{0} q_{0} L_{0}=p_{0} R_{1}+q_{n} L_{1}-q_{0} L_{0}
$$


For period 2 onwards this equality reads as

$$
c_{n} L_{t}+r_{n} q_{n} L_{t-1}=p_{n} R_{t}+q_{n}\left(L_{t}-L_{t-1}\right) \text {. }
$$

From these equations we obtain for the new contribution rate

$$
c_{n}=\frac{1}{1+r_{n}} p_{n}+\frac{s_{n}+r_{n}}{\left(1-s_{0}\right)\left(1+r_{n}\right)} p_{0}-\frac{\left(s_{n}+r_{n}\right)\left(1+r_{0}\right)}{\left(1-s_{0}\right)\left(1+r_{n}\right)} q_{0}
$$

and for the degree of funding

$$
q_{n}=\frac{1}{1+r_{n}} p_{n}-\frac{1-s_{n}}{\left(1-s_{0}\right)\left(1+r_{n}\right)} p_{0}+\frac{\left(1-s_{n}\right)\left(1+r_{0}\right)}{\left(1-s_{0}\right)\left(1+r_{n}\right)} q_{0} .
$$

The special case in Table 3 in the text, Scenario 3, can be obtained by setting $p_{n}=p_{0}=$ $30 \%, s_{0}=0, s_{n}=0.2, q_{0}=0$ and $r_{n}=r_{0}=50 \%$. The case of increased longevity referred in the text can be obtained with these same parameters except by setting $p_{n}=33 \%$, and $s_{n}$ $=s_{0}=0$.

The extreme case of full funding is derived by setting the initial fund $q_{0}=p_{0} /\left(1+r_{0}\right)$. This leads to simple expressions for $c_{n}$ and $q_{n}$, which do not depend on fertility. Correspondingly, it shows that with less than full funding the contribution rate and the degree of funding should always change with a change in fertility, if the current and future generations are treated equally. 


\section{References:}

Barr, Nicholas (2000), "Reforming Pensions: Myths, Truths, and Policy Choices", IMF WP/00/139

Brooks, Robin (2000), "What will happen to financial markets when the baby boomers retire?", IMF WP/00/18.

Cangiano, Marco, Cottarelli, Cubeddu, Luis (1998), "Pension Developments and Reforms in Transition Economies", IMF WP/98/151.

Chand, S.K. and Jaeger, A. (1996), “Aging Populations and Public Pension Schemes", International Monetary Fund, Occasional Paper 147.

Cremer, Helmuth and Pestieau, Pierre (2000) "Reforming our pension system: Is it a demographic, financial or political problem?”, European Economic Review 44, p. 974983.

Diamond, Peter (1999), Comment on the paper by Orszag and Stiglitz (below), September 1999, World Bank web-site.

Eatwell, John (1999), "The Anatomy of the Pensions 'Crisis",, in UN Economic Commission for Europe, Economic Survey of Europe 3/1999, containing papers from a seminar in May 1999.

Holzmann, Robert (1999a), "The World Banks Approach to Pension Reform", September 1999, Worldbank web-site.

Holzmann, R., Palacios, R. and Zviniene, A. (2000), "On the Economics and Scope of Implicit Pension Debt: An International Perspective", Paper prepared for ASSA Meetings, New Orleans, USA, January 2001.

Lassila, J. and Valkonen, T. (2000), "Pension Prefunding, Ageing, and Demographic Uncertainly", The Research Institute of the Finnish Economy, Discussion Papers, No. 741.

Lassila, J. and Valkonen, T. (2001), "Prefunding in a defined benefit pension system the Finnish Case", forthcoming in Social Security Pension Reform in Europe, edited by Martin Feldstein and Horst Siebert, The University of Chicago Press.

Lindeman, D., Rutkowski, M. and Sluchynskyy (2000), The Evolution of Pension Systems in Eastern Europe and Central Asia, The World Bank.

Mc Morrow, K. and Roeger, W. (1999), "The Economic Consequences of Ageing Populations", Economic Papers, Number 138, European Commission, DirectorateGeneral for Economic and Financial Affairs.

Merrill Lynch (2000), "Demographics and the Funded Pension System”.

Müller, Katarina (2000), "From the State to the Market? Pension Reform Paths in CEE and in the Former Soviet Union", Monthly Report 6/2000, The Vienna Institute for International Studies (WIIW). 
Orszag, J.M. and Orszag, P.R. (2000), "The Benefits of Flexible Funding: Implications for Pension Reform in an Uncertain World", ABCDE 2000 Conference, The World Bank, April 2000.

Orszag, Peter R. and Stiglitz. Joseph E., "Rethinking Pension Reform: Ten Myths About Social Security Systems", Conference on New ideas about old age security, September 1999, World Bank web-site.

Sinn, Hans-Werner (1997), "The Value of Children and Immigrants in a Pay-As-You-Go Pension System: a proposal for a Partial Transition to a Funded System", CESifo Working Paper 141.

Sinn, Hans-Werner (2000), "Why a Funded System is Useful and Why it is Not Useful". International Tax and Public Finance, 7, p. 89-410, originally presented at the $55^{\text {th }}$ IIPF Congress in August 1999.

UN Economic Commission for Europe, Economic Survey of Europe 3/1999, containing papers from a seminar in May 1999.

The World Bank "Averting the Old Age Crisis, Policies to Protect the Old and Promote Growth", 1994. 


\section{Economic Papers*}

The following papers have been issued. Copies may be obtained by applying to the address:

European Commission, Directorate-General for Economic and Financial Affairs

200, rue de la Loi (BU-1, -1/10)

1049 Brussels, Belgium

No. 1 EEC-DG II inflationary expectations. Survey based inflationary expectations for the EEC countries, by F. Papadia and V. Basano (May 1981).

No. 3 A review of the informal Economy in the European Community, By Adrian Smith (July 1981).

No. 4 Problems of interdependence in a multipolar world, by Tommaso Padoa-Schioppa (August 1981).

No. 5 European Dimensions in the Adjustment Problems, by Michael Emerson (August 1981).

No. 6 The bilateral trade linkages of the Eurolink Model : An analysis of foreign trade and competitiveness, by P. Ranuzzi (January 1982).

No. 7 United Kingdom, Medium term economic trends and problems, by D. Adams, S. Gillespie, M. Green and H. Wortmann (February 1982).

No. 8 Où en est la théorie macroéconomique, par E. Malinvaud (juin 1982).

No. 9 Marginal Employment Subsidies : An Effective Policy to Generate Employment, by Carl Chiarella and Alfred Steinherr (November 1982).

No. 10 The Great Depression: A Repeat in the 1980s ?, by Alfred Steinherr (November 1982).

No. 11 Evolution et problèmes structurels de l'économie néerlandaise, par D.C. Breedveld, C. Depoortere, A. Finetti, Dr. J.M.G. Pieters et C. Vanbelle (mars 1983).

No. 12 Macroeconomic prospects and policies for the European Community, by Giorgio Basevi, Olivier Blanchard, Willem Buiter, Rudiger Dornbusch, and Richard Layard (April 1983).

No. 13 The supply of output equations in the EC-countries and the use of the survey-based inflationary expectations, by Paul De Grauwe and Mustapha Nabli (May 1983).

No. 14 Structural trends of financial systems and capital accumulation : France, Germany, Italy, by G. Nardozzi (May 1983).

No. 15 Monetary assets and inflation induced distorsions of the national accounts - conceptual issues and correction of sectoral income flows in 5 EEC countries, by Alex Cukierman and Jorgen Mortensen (May 1983).

No. 16 Federal Republic of Germany. Medium-term economic trends and problems, by F. Allgayer, S. Gillespie, M. Green and H. Wortmann (June 1983).

No. 17 The employment miracle in the US and stagnation employment in the EC, by M. Wegner (July 1983).

No. 18 Productive Performance in West German Manufacturing Industry 1970-1980; A Farrell Frontier Characterisation, by D. Todd (August 1983).

No. 19 Central-Bank Policy and the Financing of Government Budget Deficits : A Cross-Country Comparison, by G. Demopoulos, G. Katsimbris and S. Miller (September 1983).

\section{* Issues 1 to 115 are out of print}


No. 20 Monetary assets and inflation induced distortions of the national accounts. The case of Belgium, by Ken Lennan (October 1983).

No. 21 Actifs financiers et distorsions des flux sectoriels dues à l'inflation: le cas de la France, par J.P Baché (octobre 1983).

No. 22 Approche pragmatique pour une politique de plein emploi : les subventions à la création d'emplois, par A. Steinherr et B. Van Haeperen (octobre 1983).

No. 23 Income Distribution and Employment in the European Communities 1960-1982, by A. Steinherr (December 1983).

No. 24 U.S. Deficits, the dollar and Europe, by O. Blanchard and R. Dornbusch (December 1983).

No. 25 Monetary Assets and inflation induced distortions of the national accounts. The case of the Federal Republic of Germany, by H. Wittelsberger (January 1984).

No. 26 Actifs financiers et distorsions des flux sectoriels dues à l'inflation : le cas de l'Italie, par A. Reati (janvier 1984).

No. 27 Evolution et problèmes structurels de l'économie italienne, par Q. Ciardelli, F. Colasanti et X. Lannes (janvier 1984).

No. 28 International Co-operation in Macro-economic Policies, by J.E. Meade (February 1984).

No. 29 The Growth of Public Expenditure in the EEC Countries 1960-1981 : Some Reflections, by Douglas Todd (December 1983).

No. 30 The integration of EEC qualitative consumer survey results in econometric modelling : an application to the consumption function, by Peter Praet (February 1984).

No. 31 Report of the CEPS Macroeconomic Policy Group. EUROPE : The case for unsustainable growth, by R. Layard, G. Basevi, O. Blanchard, W. Buiter and R. Dornbusch (April 1984).

No. 32 Total Factor Productivity Growth and the Productivity Slowdown in the West German Industrial Sector, 1970-1981, by Douglas Todd (April 1984).

No. 33 An analytical Formulation and Evaluation of the Existing Structure of Legal Reserve Requirements of the Greek Economy : An Uncommon Case, by G. Demopoulos (June 1984).

No. 34 Factor Productivity Growth in Four EEC Countries, 1960-1981, by Douglas Todd (October 1984).

No. 35 Rate of profit, business cycles and capital accumulalion in U.K. industry, 1959-1981, by Angelo Reati (November 1984).

No. 36 Report of the CEPS Macroeconomic Policy Group. Employment and Growth in Europe : A Two-Handed Approach by P. Blanchard, R. Dornbush, J. Drèze, H. Giersch, R. Layard and M. Monti (June 1985).

No. 37 Schemas for the construction of an "auxiliary econometric model" for the social security system, by A. Coppini and G. Laina (June 1985).

No. 38 Seasonal and Cyclical Variations in Relationship among Expectations, Plans and Realizations in Business Test Surveys, by H. König and M. Nerlove (July 1985).

No. 39 Analysis of the stabilisation mechanisms of macroeconomic models : a comparison of the Eurolink models by A. Bucher and V. Rossi (July 1985).

No. 40 Rate of profit, business cycles and capital accumulation in West German industry, 1960-1981, by A. Reati (July 1985).

No. 41 Inflation induced redistributions via monetary assets in five European countries : 1974-1982, by A. Cukierman, K. Lennan and F. Papadia (September 1985). 
No. 42 Work Sharing: Why ? How ? How not ..., by Jacques H. Drèze (December 1985).

No. 43 Toward Understanding Major Fluctuations of the Dollar by P. Armington (January 1986).

No. 44 Predictive value of firms' manpower expectations and policy implications, by G. Nerb (March 1986).

No. 45 Le taux de profit et ses composantes dans l'industrie française de 1959 à 1981, par Angelo Reati (mars 1986).

No. 46 Forecasting aggregate demand components with opinions surveys in the four main ECCountries - Experience with the BUSY model, by M. Biart and P. Praet (May 1986).

No. 47 Report of CEPS Macroeconomic Policy Group : Reducing Unemployment in Europe : The Role of Capital Formation, by F. Modigliani, M. Monti, J. Drèze, H. Giersch and R. Layard (July 1986).

No. 48 Evolution et problèmes structurels de l'économie française, par X. Lannes, B. Philippe et P. Lenain (août 1986).

No. 49 Long run implications of the increase in taxation and public debt for employment and economic growth in Europe, by G. Tullio (August 1986).

No. 50 Consumers Expectations and Aggregate Personal Savings, by Daniel Weiserbs and Peter Simmons (November 1986).

No. 51 Do after tax interest affect private consumption and savings ? Empirical evidence for 8 industrial countries : 1970-1983, by G. Tullio and Fr. Contesso (December 1986).

No. 52 Validity and limits of applied exchange rate models : a brief survey of some recent contributions, by G. Tullio (December 1986).

No. 53 Monetary and Exchange Rate Policies for International Financial Stability : a Proposal, by Ronald I. McKinnon (November 1986).

No. 54 Internal and External Liberalisation for Faster Growth, by Herbert Giersch (February 1987).

No. 55 Regulation or Deregulation of the Labour Market : Policy Regimes for the Recruitment and Dismissal of Employees in the Industrialised Countries, by Michael Emerson (June 1987).

No. 56 Causes of the development of the private ECU and the behaviour of its interest rates : October 1982 - September 1985, by G. Tullio and Fr. Contesso (July 1987).

No. 57 Capital/Labour substitution and its impact on employment, by Fabienne Ilzkovitz (September 1987).

No. 58 The Determinants of the German Official Discount Rate and of Liquidity Ratios during the classical goldstandard: 1876-1913, by Andrea Sommariva and Giuseppe Tullio (September 1987).

No. 59 Profitability, real interest rates and fiscal crowding out in the OECD area 1960-1985 (An examination of the crowding out hypothesis within a portfolio model), by Jorgen Mortensen (October 1987).

No. 60 The two-handed growth strategy for Europe : Autonomy through flexible cooperation, by J. Drèze, Ch. Wyplosz, Ch. Bean, Fr. Giavazzi and H. Giersch (October 1987).

No. 61 Collusive Behaviour, R \& D, and European Policy, by Alexis Jacquemin (Novemher 1987).

No. 62 Inflation adjusted government budget deficits and their impact on the business cycle : empirical evidence for 8 industrial countries, by G. Tullio (November 1987).

No. 63 Monetary Policy Coordination Within the EMS: Is there a Rule ?, by M. Russo and G. Tullio (April 1988). 
No. 64 Le Découplage de la Finance et de l'Economie - Contribution à l'Evaluation des Enjeux Européens dans la Révolution du Système Financier International par J.-Y. Haberer (mai 1988).

No. 65 The completion of the internal market : results of macroeconomic model simulations, by M. Catinat, E. Donni and A. Italianer (September 1988).

No. 66 Europe after the crash : economic policy in an era of adjustment, by Charles Bean (September 1988).

No. 67 A Survey of the Economies of Scale, by Cliff Pratten (October 1988).

No. 68 Economies of Scale and Intra-Community trade, by Joachim Schwalbach (October 1988).

No. 69 Economies of Scale and the Integration of the European Economy : the Case of Italy, by Rodolfo Helg and Pippo Ranci (October 1988).

No 70 The Costs of Non-Europe - An assessment based on a formal Model of Imperfect Competition and Economies of Scale, by A. Smith and A. Venables (October 1988).

No. 71 Competition and Innovation, by P.A. Geroski (October I 988).

No. 72 Commerce Intra-Branche - Performances des firmes et analyse des échanges commerciaux dans 1a Communauté européenne par le Centre d'Etudes Prospectives et d'Informations Internationales de Paris (octobre 1988).

No. 73 Partial Equilibrium Calculations of the Impact of Internal Market Barriers in the European Community, by Richard Cawley and Michael Davenport (October 1988).

No. 74 The exchange-rate question in Europe, by Francesco Giavazzi (January 1989).

No. 75 The QUEST model (Version 1988), by Peter Bekx, Anne Bucher, Alexander Italianer, Matthias Mors (March 1989).

No. 76 Europe's Prospects for the 1990s, by Herbert Giersch (May 1989).

No. 77 1992, Hype or Hope : A review, by Alexander Italianer (February 1990).

No. 78 European labour markets : a long run view (CEPS Macroeconomic Policy Group 1989 Annual Report), by J.-P. Danthine, Ch. Bean, P. Bernholz and E. Malinvaud (February 1990).

No. 79 Country Studies - The United Kingdom, by Tassos Belessiotis and Ralph Wilkinson (July 1990).

No. 80 See "Länderstudien" No. 1

No. 81 Country Studies - The Netherlands, by Filip Keereman, Françoise Moreau and Cyriel Vanbelle (July 1990).

No. 82 Country Studies - Belgium, by Johan Baras, Filip Keereman and Françoise Moreau (July 1990).

No. 83 Completion of the internal market : An application of Public Choice Theory, by Manfred Teutemann (August 1990).

No. 84 Monetary and Fiscal Rules for Public Debt Sustainability, by Marco Buti (September 1990).

No. 85 Are we at the beginning of a new long term expansion induced, by technological change ?, by Angelo Reati (August 1991).

No. 86 Labour Mobility, Fiscal Solidarity and the Exchange Rate Regime : a Parable of European Union and Cohesion, by Jorge Braga de Macedo (October 1991).

No. 87 The Economics of Policies to Stabilize or Reduce Greenhouse Gas Emissions : the Case of CO2, by Mathias Mors (October 1991). 
No. 88 The Adequacy and Allocation of World Savings, by Javier Santillán (December 1991).

No. 89 Microeconomics of Saving, by Barbara Kauffmann (December 1991).

No. 90 Exchange Rate Policy for Eastern Europe and a Peg to the ECU, by Michael Davenport (March 1992).

No. 91 The German Economy after Unification : Domestic and European Aspects, by Jürgen Kröger and Manfred Teutemann (April 1992).

No. 92 Lessons from Stabilisation Programmes of Central and Eastern European Countries, 1989-91, by Domenico Mario Nuti (May 1992).

No. 93 Post-Soviet Issues : Stabilisation, Trade and Money, by D. Mario Nuti and Jean Pisani-Ferry (May 1992).

No. 94 Regional Integration in Europe by André Sapir (September 1992).

No. 95 Hungary : Towards a Market Economy (October 1992).

No. 96 Budgeting Procedures and Fiscal Performance in the European Communities, by Jürgen von Hagen (October 1992).

No. 97 L'ECU en poche ? Quelques réflexions sur la méthode et le coût du remplacement des monnaies manuelles nationales par des pièces et des billets en ECU, par Ephraïm Marquer (octobre 1992).

No. 98 The Role of the Banking Sector in the Process of Privatisation, by Domenico Mario Nuti (November 1992).

No. 99 Towards budget discipline : an economic assessment of the possibilities for reducing national deficits in the run-up to EMU, by Dr. J. de Haan, Dr. C.G.M. Sterks and Prof. Dr. C.A. de Kam (December 1992).

No. 100 EC Enlargement and the EFTA Countries, by Christopher Sardelis (March 1993).

No. 101 Agriculture in the Uruguay Round : ambitions and realities, by H. Guyomard, L.-P. Mahé, K. Munk and T. Roe (March 1993).

No. 102 Targeting a European Monetary Aggregate, Review and Current Issues, by Christopher Sardelis (July 1993).

No. 103 What Have We Learned About the Economic Effects of EC Integration ? - A Survey of the Literature, by Claudia Ohly (September 1993).

No. 104 Measuring the Term Structure of ECU Interest Rates, by Johan Verhaeven and Werner Röger (October 1993).

No. 105 Budget Deficit and Interest Rates : Is there a Link ? International evidence, by José NunesCorreia and Loukas Stemitsiotis (November 1993).

No. 106 The Implications for Firms and Industry of the Adoption of the ECU as the Single Currency in the EC, by M. Burridge and D.G. Mayes (January 1994).

No. 107 What does an economist need to know about the environment ? Approaches to accounting for the environment in statistical informations systems, by Jan Scherp (May 1994).

No. 108 The European Monetary System during the phase of transition to European Monetary Union, by Dipl.-Vw. Robert Vehrkamp (July 1994).

No. 109 Radical innovations and long waves into Pasinetti's model of structural change : output and employment, by Angelo Reati (March 1995).

No. 110 Pension Liabilities - Their Use and Misuse in the Assessment of Fiscal Policies, by Daniele Franco (May 1995). 
No. 111 The Introduction of Decimal Currency in the UK in 1971. Comparisons with the Introduction of a Single European Currency, by N.E.A. Moore (June 1995).

No. 112 Cheque payments in Ecu - A Study of Cross-Border Payments by Cheques in Ecu Across the European Union, by BDO Stoy Hayward Management Consultants (July 1995).

No. 113 Banking in Ecu - A Survey of Banking Facilities across the European Union in the ECU, Deutschmark and Dollar and of Small Firms' Experiences and Opinions of the Ecu, by BDO Stoy Hayward Management Consultants (July 1995).

No. 114 Fiscal Revenues and Expenditure in the Community. Granger-Causality Among Fiscal Variables in Thirteen Member States and Implications for Fiscal Adjustment, by Tassos Belessiotis (July 1995).

No. 115 Potentialities and Opportunities of the Euro as an International Currency, by Agnès BénassyQuéré (July 1996).

No. 116 Consumer confidence and consumer spending in France, by Tassos Belessiotis (September 1996).

No. 117 The taxation of Funded Pension Schemes and Budgetary Policy, by Daniele Franco (September 1996).

No. 118 The Wage Formation Process and Labour Market Flexibility in the Community, the US and Japan, by Kieran Mc Morrow (October 1996).

No. 119 The Policy Implications of the Economic Analysis of Vertical Restraints, by Patrick Rey and Francisco Caballero-Sanz (November 1996).

No. 120 National and Regional Development in Central and Eastern Europe: Implications for EU Structural Assistance, by Martin Hallet (March 1997).

No. 121 Budgetary Policies during Recessions, - Retrospective Application of the "Stability and Growth Pact" to the Post-War Period -, by M. Buti, D. Franco and H. Ongena (May 1997).

No. 122 A dynamic analysis of France's external trade - Determinants of merchandise imports and exports and their role in the trade surplus of the 1990s, by Tassos Belessiotis and Giuseppe Carone (October 1997).

No. 123 QUEST II - A Multi Country Business Cycle and Growth Model, by Werner Roeger and Jan in't Veld (October 1997).

No. 124 Economic Policy in EMU - Part A : Rules and Adjustment, by Directorate General II, Economic and Financial Affairs (November 1997).

No. 125 Economic Policy in EMU - Part B : Specific Topics, by Directorate General II, Economic and Financial Affairs (November 1997).

No. 126 The Legal Implications of the European Monetary Union under the U.S. and New York Law, by Niall Lenihan (January 1998).

No. 127 Exchange Rate Variability and EU Trade, by Khalid Sekkat (February 1998).

No. 128 Regionalism and the WTO: New Rules for the Game?, by Nigel Nagarajan (June 1998).

No. 129 MERCOSUR and Trade Diversion: What Do The Import Figures Tell Us?, by Nigel Nagarajan (July 1998).

No. 130 EUCARS: A partial equilibrium model of EUropean CAR emissions (Version 3.0), by Cécile Denis and Gert Jan Koopman (November 1998).

No. 131 Is There a Stable Money Demand Equation at The Community Level? - Evidence, using a cointegration analysis approach, for the Euro-zone countries and for the Community as a whole -, by Kieran Mc Morrow (November 1998). 
No. 132 Differences in Monetary Policy Transmission? A Case not Closed, by Mads Kieler and Tuomas Saarenheimo (November 1998).

No. 133 Net Replacement Rates of the Unemployed. Comparisons of Various Approaches, by Aino Salomäki and Teresa Munzi (February 1999).

No. 134 Some unpleasant arithmetics of regional unemployment in the EU. Are there any lessons for the EMU?, by Lucio R. Pench, Paolo Sestito and Elisabetta Frontini (April 1999).

No. 135 Determinants of private consumption, by A. Bayar and K. Mc Morrow (May 1999).

No. 136 The NAIRU Concept - Measurement uncertainties, hysteresis and economic policy role, by P. McAdam and K. Mc Morrow (September 1999).

No. 137 The track record of the Commission Forecasts, by F. Keereman (October 1999).

No. 138 The economic consequences of ageing populations (A comparison of the EU, US and Japan), by K. Mc Morrow and W. Roeger (November 1999).

No. 139 The millennium round: An economic appraisal, by Nigel Nagarajan (November 1999).

No. 140 Disentangling Trend and Cycle in the EUR-11 Unemployment Series - An Unobserved Component Modelling Approach, by Fabrice Orlandi and Karl Pichelmann (February 2000)

No. 141 Regional Specialisation and Concentration in the EU, by Martin Hallet (February 2000)

No. 142 The Location of European Industry, by K.H. Midelfart-Knarvik, H.G. Overman, S.J. Redding and A.J. Venables (April 2000)

No. 143 Report on Financial Stability, by the Economic and Financial Committee (EFC) (May 2000)

No. 144 Estimation of Real Equilibrium Exchange Rates, by Jan Hansen and Werner Roeger (September 2000)

No. 145 Time-Varying Nairu/Nawru Estimates for the EU's Member States, by K. McMorrow and W. Roeger (September 2000)

No. 146 ECFIN's Effective tax rates. Properties and Comparisons with other tax indicators, by Carlos Martinez-Mongay (October 2000)

No. 147 The Contribution of Information and Communication Technologies to Growth in Europe and the US: A Macroeconomic Analysis, by Werner Roeger (January 2001)

No. 148 Budgetary Consolidation in EMU by Jürgen von Hagen (ZEI, University of Bonn, Indiana University, and CEPR), Andrew Hughes Hallett (Strathclyde University, Glasgow, and CEPR), Rolf Strauch (ZEI, University of Bonn) (March 2001)

No. 149 A Case for Partial Funding of Pensions with an Application to the EU Candidate Countries by Heikki Oksanen 


\section{Euro Papers}

The following papers have been issued. Copies may be obtained by applying to the address:

European Commission, Directorate-General for Economic and Financial Affairs

200, rue de la Loi (BU-1, -1/10)

1049 Brussels, Belgium

No. 1 External aspects of economic and monetary union, by Directorate General II, Economic and Financial Affairs (July 1997).

No. 2 Accounting for the introduction of the euro, by Directorate General XV, Internal Market and Financial Services (July 1997).

No. 3 The impact of the introduction of the euro on capital markets, by Directorate General II, Economic and Financial Affairs (July 1997).

No. 4 Legal framework for the use of the euro, by Directorate General II, Economic and Financial Affairs

(September 1997).

No. 5 Round Table on practical aspects of the changeover to the euro -May 15, 1997 Summary and conclusions, by Directorate General II, Economic and Financial Affairs (September 1997).

No. 6 Checklist on the introduction of the euro for enterprises and auditors, by Fédération des Experts Comptables Européens (September 1997).

No. 7 The introduction of the euro-Compilation of community legislation and related documents, by Directorate General II, Economic and Financial Affairs (October 1997).

No. 8 Practical aspects of the introduction of the euro, by Directorate General II, Economic and Financial Affairs (November 1997).

No. 9 The impact of the changeover to the euro on community policies, institutions and legislation, by Directorate General II, Economic and Financial Affairs (November 1997).

No. 10 Legal framework for the use of the euro - Questions and answers on the euro regulations, by Directorate General II, Economic and Financial Affairs (December 1997).

No. 11 Preparing Financial Information Systems for the euro, by Directorate General XV, Internal Market and Financial Services (December 1997).

No. 12 Preparations for the changeover of public administrations to the euro, by Directorate General II, Economic and Financial Affairs (December 1997).

No. 13 Report of the Expert Group on Technical and Cost Aspects of Dual Display, by Directorate General II, Economic and Financial Affairs (December 1997).

No. 14 Report of the Expert Group on banking charges for conversion to the euro, by Directorate General XV, Internal Market and Financial Services (January 1998).

No. 15 The Legal Implications of the European Monetary Union under the U.S. and New York Law, by Niall Lenihan, (Study commissioned by Directorate General II, Economic and Financial Affairs) (January 1998). 
No. 16 Commission Communication on the information strategy for the euro, by Directorate General X, Information, communication, culture, audiovisual communication and Directorate General II, Economic and Financial Affairs (February 1998).

No. 17 The euro: explanatory notes, by Directorate General II, Economic and Financial Affairs (February 1998).

No. 18 Report by the Working Group on "Acceptance of the new prices and scales of values in euros", by Directorate General XXIII, Enterprise Policy, Distributive Trades, Tourism and Social Economy and Directorate General XXIV, Consumer Policy Service (February 1998).

No. 19 Report of the Expert Working Group "Euro-Education”, by Directorate General XXII, Education, Training and Youth (February 1998).

No. 20 Report by the Working Party "Small businesses and the euro", by Directorate General XXIII, Enterprise Policy, Distributive Trades, Tourism and Social Economy (February 1998).

No. 21 Update on the practical aspects of the introduction of the euro, by Directorate General II, Economic and Financial Affairs (February 1998).

No. 22 The introduction of the euro and the rounding of currency amounts, by Directorate General II, Economic and Financial Affairs (March 1998).

No. 23 From Round Table to Recommendations on practical aspects of the introduction of the euro, by Directorate General II, Economic and Financial Affairs (May 1998).

No. 24 The impact of the euro on Mediterranean partner countries, by Jean-Pierre Chauffour and Loukas Stemitsiotis, Directorate General II, Economic and Financial Affairs (June 1998).

No. 25 The introduction of the euro - Addendum to the compilation of community legislation and related documents, by Directorate General II, Economic and Financial Affairs (July 1998).

No. 26 The implications of the introduction of the euro for non-EU countries, by Peter Bekx, Directorate General II, Economic and Financial Affairs (July 1998).

No. 27 Fact sheets on the preparation of national public administrations to the euro (Status : 15 May 1998), by Directorate General II, Economic and Financial Affairs (July 1998).

No. 28 Debt redenomination and market convention in stage III of EMU, by Monetary Committee (July 1998).

No. 29 Summary of experts' reports compiled for the euro working group/European Commission - DG XXIV on psycho-sociological aspects of the changeover to the euro, by Directorate General XXIV, Consumer Policy and Consumer Health Protection (November 1998).

No. 30 Implementation of the Commission Recommendation on banking charges for the conversion to the euro, by Directorate General XV, Internal Market and Financial Services, Directorate General II, Economic and Financial Affairs and Directorate General XXIV, Consumer Policy and Consumer Health Protection (December 1998). 
No. 31 How large companies could help their small suppliers and distributors change over to the euro. Proceedings and conclusions of the Workshop held on 5 November 1998 in Brussels. Organised by the Directorate General II and The Association for the Monetary Union of Europe (January 1999).

No. 32 Risk capital markets, a key to job creation in Europe. From fragmentation to integration - Report prepared by Delphine Sallard, Directorate General II, Economic and Financial Affairs, on a conference organised by the European Commission on 24 November 1998, in Brussels (January 1999).

No. 33 The impact of the changeover to the euro on community policies, institutions and legislation (Progress towards implementing the Commission's Communication of November 1997), by Directorate General II, Economic and Financial Affairs (April 1999).

No. 34 Duration of the transitional period related to the introduction of the euro (Report from the Commission to the Council), by Directorate General II, Economic and Financial Affairs (April 1999).

No. 35 EU Repo markets: opportunities for change, (Report of the Giovannini Group) (October 1999).

No. 36 Migrating to euro - System strategies \& best practices recommendations for the adaptation of information systems to the euro, (Report by the Euro Working Group) (October 1999).

No. 37 Euro coins - From design to circulation, by Directorate-General ECFIN, Economic and Financial Affairs (May 2000)

No. 38 Communication from the Commission on communications strategy in the last phases of the completion of EMU, by Directorate General II, Economic and Financial Affairs (August 2000).

No. 39 Changing to the euro - What would happen to a company on 1 January 2002 that had not converted to the euro? Advice to managers and their advisers, by Fédération des Experts Comptables Européens (August 2000)

No. 40 Conference "Enterprises 2002" - 6 June 2000. A round table on the practical impact on enterprises at the end of the "transition period"by Directorate General for Economic and Financial Affairs, August 2000

No. 41 Communication from the Commission on the practical aspects of the euro: state of play and tasks ahead, by Directorate General II, Economic and Financial Affairs (August 2000). 